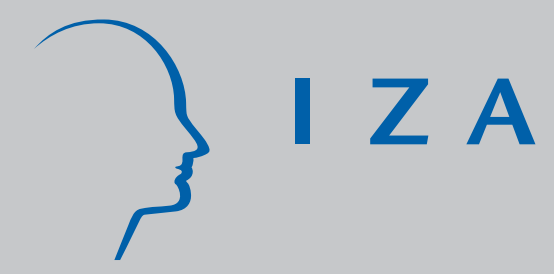

IZA DP No. 4009

The Puzzle of Muslim Advantage in Child Survival in India

Sonia Bhalotra

Christine Valente

Arthur van Soest

February 2009 


\title{
The Puzzle of Muslim Advantage in Child Survival in India
}

\author{
Sonia Bhalotra \\ University of Bristol \\ and IZA \\ Christine Valente \\ University of Nottingham \\ Arthur van Soest \\ Tilburg University \\ and IZA

\section{Discussion Paper No. 4009 \\ February 2009} \\ IZA \\ P.O. Box 7240 \\ 53072 Bonn \\ Germany \\ Phone: +49-228-3894-0 \\ Fax: +49-228-3894-180 \\ E-mail: iza@iza.org
}

Any opinions expressed here are those of the author(s) and not those of IZA. Research published in this series may include views on policy, but the institute itself takes no institutional policy positions.

The Institute for the Study of Labor (IZA) in Bonn is a local and virtual international research center and a place of communication between science, politics and business. IZA is an independent nonprofit organization supported by Deutsche Post Foundation. The center is associated with the University of Bonn and offers a stimulating research environment through its international network, workshops and conferences, data service, project support, research visits and doctoral program. IZA engages in (i) original and internationally competitive research in all fields of labor economics, (ii) development of policy concepts, and (iii) dissemination of research results and concepts to the interested public.

IZA Discussion Papers often represent preliminary work and are circulated to encourage discussion. Citation of such a paper should account for its provisional character. A revised version may be available directly from the author. 
IZA Discussion Paper No. 4009

February 2009

\section{ABSTRACT}

\section{The Puzzle of Muslim Advantage in Child Survival in India*}

The socio-economic status of Indian Muslims is, on average, considerably lower than that of upper caste Hindus. Muslims have higher fertility and shorter birth spacing and are a minority group that, it has been argued, have poorer access to public goods. They nevertheless exhibit substantially higher child survival rates, and have done for decades. This paper documents and analyses this seeming puzzle. The religion gap in survival is much larger than the gender gap but, in contrast to the gender gap, it has not received much political or academic attention. A decomposition of the survival differential reveals that some compositional effects favour Muslims but that, overall, differences in characteristics between the communities and especially the Muslim deficit in parental education predict a Hindu advantage. Alternative outcomes and specifications support our finding of a Muslim fixed effect that favours survival. The results of this study contribute to a recent literature that debates the importance of socioeconomic status (SES) in determining health and survival. They augment a growing literature on the role of religion or culture as encapsulating important unobservable behaviours or endowments that influence health, indeed, enough to reverse the SES gradient that is commonly observed.

JEL Classification: $\quad 012, \mathrm{I12}, \mathrm{J15}, \mathrm{J} 16, \mathrm{~J} 18$

Keywords: religion, caste, gender, child survival, anthropometrics, Hindu, Muslim, India

Corresponding author:

Sonia Bhalotra

Department of Economics

University of Bristol

8 Woodland Road

Bristol BS8 1TN

United Kingdom

E-mail: s.bhalotra@bristol.ac.uk

\footnotetext{
* Sonia Bhalotra acknowledges funding from ESRC and DFID under research grant RES-167-25-0236 held at the CMPO in Bristol. Earlier versions of this paper were presented at a DFID and CMPO funded workshop on Child Health in Developing Countries in Bristol in June 2005 and at the European Society of Population Economics Conference in Verona in June 2006.
} 


\section{The Puzzle Of Muslim Advantage In Child Survival In India}

Sonia Bhalotra, Christine Valente, Arthur van Soest

\section{Introduction}

Hindus and Muslim have cohabited in India for centuries, with Muslims ruling most of the Indian subcontinent from the early 16th to the mid-19th centuries under the Mughal Empire. However, today, their socioeconomic condition is thought to be not much better than that of low caste Hindus, who have a long history of deprivation (Government of India 2006). ${ }^{1}$ But despite being, on average, less educated and poorer, Indian Muslims exhibit a substantial advantage in child survival. This paper documents and analyses this seeming puzzle. It shows that the Muslim advantage is large, persistent, and hard to explain.

A number of recent studies document socioeconomic status (SES) gradients in health and survival, across countries, across SES groups within country and within groups over time; for a survey see Cutler et al. (2006). Previous analyses of health inequalities along ethnic or religious lines tend to start out with a differential consistent with SES differences, as is the case, for example, with black-white differences in health in the United States. While it has been recognised that unhealthy behaviours like smoking or drinking may vary positively with SES (e.g. Rogers et al., 2000, p. 245), these are seldom large enough to alter the raw differential in favour of the lower-SES group. The case of Muslims in India is, in this respect, most unusual.

By age five, the Muslim survival advantage over Hindus is as high as $2.31 \%$ points, which is about $17 \%$ of baseline mortality risk amongst Hindus. Restricting the comparison to upper-caste Hindus, who enjoy unambiguously higher social status than Muslims, the differential is $1.30 \%$-points, or about $10 \%$ of baseline mortality risk. Based on the total number of births recorded in 2000 (Census of India 2001), and on the proportions of high- and low-caste children born that year (obtained from representative survey data used in this paper), this differential translates into an annual 127,955 $(244,535)$ excess under-5 deaths amongst high-caste (low-caste) Hindus. To put the size of this differential in perspective, consider that the more widely discussed gender differential in under-5 mortality is $0.30 \%$-points. Also, the average annual rate of decrease in under-5 mortality risk between 1960 and 2001 in India was 0.61\%-points p.a.,

\footnotetext{
${ }^{1}$ This is topical because the last two decades have witnessed renewed conflict between Hindus and Muslims (Varshney 2002), and this has also been a period of considerable political and socio-economic change.
} 
which is about half the differential between Muslims and high-caste Hindus. The Muslim-Hindu survival differential is not a new or an isolated phenomenon. It is evident for most of the last half century. It has nevertheless claimed little public or academic attention. Although it is flagged by Shariff (1995), Bhat and Zavier (2005), Bhalotra and van Soest (2008) and Deolalikar (forthcoming), we know of no previous research that carefully investigates this phenomenon.

This paper attempts to fill this gap, using microdata on more than 0.6 million children born to about 200,000 Indian women during 1960-2006. The data and context are described in Section 2. Section 3 profiles the seeming puzzle, showing how the Muslim advantage varies by gender, age and birth order, how it has evolved over time, and how it differs across Indian states and between rural and urban areas. Section 4 presents the estimation methods used. We use existing techniques for decomposition of outcome differentials to investigate the extent to which the mortality differential can be explained by the sorts of characteristics that are commonly used to explain or predict child mortality rates (results are in Section 5). We then investigate alternative outcomes and specifications (Section 6). Section 7 concludes. Our main finding is that the Muslim advantage over high caste Hindus cannot be explained by the usual covariates included in the model.

It is possible that there are omitted variables that improve survival and that are inversely correlated with SES, but that have no particular relation to religion. The layering of religion and caste in Indian society provides us with an opportunity to investigate this. We do this by considering the extent to which the Muslim advantage over low caste Hindus (of lower SES) is explained by the same set of characteristics. We find that less than half of their advantage is explained. Overall, the evidence points to a persistent Muslim “fixed effect” that favours child survival. The fixed effect survives our attempts to include further controls for socio-economic status, access to health services and rural infrastructure, maternal health and diet, and it is evident again when we examine differences between Hindu and Muslim communities in child nutritional status.

Our findings suggest a research agenda that investigates what attitudes, behaviours or unobserved traits Muslims might have, unlocking the key to which would make an enormous impact on average mortality rates in India. We suggest that some of the Muslim advantage may stem from their lower degree of son-preference, their closer kinship, their more non-vegetarian diet, the better health of Muslim mothers and their lower propensity to work outside the home. 
The results contribute to a recent literature that argues that socioeconomic status may not be as important a determinant of health or survival as attitudes at the individual level and medical technology and services at the aggregate level (Cutler et al. 2006, Fuchs 2004). It extends this discussion to incorporate the importance of culture or community. Although there is a surge of interest amongst economists in ethnicity effects, especially in education (e.g. Fryer and Levitt 2004, Wilson et al 2005), there remains limited research on religion effects. The effects of religion on fertility have been analysed, for example, for India (Bhat and Zavier 2005) and historical Europe (Guinnane 2005), but there is little work on religion and health. The analysis leads us to reconsider the power of commonly estimated equations for mortality and health that neglect unobserved heterogeneity between communities. The results also highlight the fact that mortality is not systematically related to other indicators of health. In particular, although the incidence of malnutrition by a cumulative indicator (height) is lower amongst children in the higher SES group (Hindus), they are nevertheless more likely to die by the age of five. This echoes the contrary patterns of malnutrition and mortality in comparisons of sub-Saharan Africa and South Asia (e.g. Klasen 2003).

\section{Background and Data}

Muslims constituted $13.4 \%$ of the Indian population in 2001, up from $9.9 \%$ in 1951. Their total fertility rate was 3.06, as compared with 2.47 for Hindu women, a 24\% differential (Census of India 2001). The Sachar Committee Report commissioned by the Indian Prime Minister documents their relatively weak social, economic and educational status (Government of India 2006, henceforth GOI). Muslims are poorer than upper caste Hindus, especially in urban areas (GOI). They have been less educated than upper caste Hindus for decades and, although Muslim women have exhibited some catch-up, Muslim men have not (Deolalikar forthcoming). There is intergenerational persistence in education, which is a mechanism for the perpetuation of Muslim disadvantage (Bhalotra et al. 2008). The educational deprivation of Muslims has been shown to drive their disadvantage in the labour market (Bhaumik and Chakrabarty 2007). Their political representation is small relative to their population share (GOI), and it has been argued that the areas in which they are concentrated receive poorer public services (GOI). Overall, the SES of Muslims is not much better than that of low caste Hindus. Yet, although there are reserved places for the low castes in higher education, in public sector jobs and in state legislatures, there is no similar positive discrimination in favour of 
Muslims. These facts all make their relative success in averting child mortality quite remarkable. $^{2}$

To investigate the mortality differential, we stack three rounds of the National Family Health Survey of India (NFHS) conducted in 1992/3, 1998/9, and 2005/06 (see IIPS 1995, IIPS and ORC Macro 2000, and IIPS and Macro International 2007). These surveys interviewed women aged 15-49 (13-49 in NFHS-1) at the time of the survey and obtained complete fertility histories, including the dates of live births and of any child deaths. The surveys contain information on relevant individual and household characteristics, and the first two rounds also include information on village characteristics including health infrastructure. Births in the original sample occur during 1954-2006. We restrict the sample to mothers who are normal residents in the dwelling in which they are interviewed. We drop children born before 1960 (0.08\% of the sample), as the sample sizes are very small for these years. We right-truncate the sample to ensure that all children analysed have full exposure to the relevant mortality risk; for instance, for under-5 mortality, we remove children less than 60 months old at the time of interview (17.43\% of births). We drop mothers who have ever had a multiple birth $3.11 \%$ of births $)^{3}$ and mothers for whom information on caste is missing ( $0.38 \%$ of all births). We also drop the $11.49 \%$ of births in the survey that occur in households of religions other than Muslim or Hindu, so that from now on, we refer to the mortality differential between Muslim and Hindus as the religion-differential. ${ }^{4}$ The largest sample analysed (namely, the one for children fully exposed to neonatal risk) has 653,496 live births of 197,952 mothers.

We pool data from across the states and include state fixed effects and trends in the model. Our objective is to address the broad question of how Muslims and Hindus in India as a whole compare although future work might focus on between-state differences. Large samples are generated from the NFHS by using the full history of births. A potential problem with this is recall bias in dates of birth and death, which is greater the

\footnotetext{
${ }^{2}$ In this paper, low caste Hindus refers to scheduled castes and tribes (SC, ST). There are also castes within the Muslim community but they do not have the same history as the Hindu lower castes and castes not listed as SC or ST do not qualify for positive discrimination.

${ }^{3}$ It is standard practice in the demographic literature to restrict the analysis to singletons as death risks are many times higher for multiple births and can skew the statistics. Amongst Muslims $1.48 \%$ of live births are multiple (twin, triplet etc) and amongst Hindus the corresponding figure is $1.29 \%$.

${ }^{4}$ Due to sampling design, the non-weighted share of births in households of religions other than Muslim or Hindu is much larger than the share of these other religions in the total population. When the number of births is corrected for sampling design, the share of the other religions is closer to figures from the population census: $4.2 \%$ of births compared to $6.1 \%$ of the population of all ages in 2001 .
} 
further back in time the event occurred. If any recall error is similar across communities then this will not matter. We allow for recall that is expressed as age heaping by defining indicators of mortality (e.g. under-5) to include deaths in the last month (e.g. $60^{\text {th }}$ ). A second possible issue is that the further back one goes in time, the more scarce and the less representative of the complete cohorts of children in these birth years is the sample of births in the birth-history data because only mothers younger than 50 were interviewed. This results in the early years including a disproportionate share of children born to young mothers. ${ }^{5}$ These mothers are likely to be poorer and have higher fertility than the average mother of children born at the same time. To account for this triangular nature of the data structure, we condition on mother's age at birth.

The heights and weights of children are indicators of the child's nutritional status (e.g. Micklewright and Ismail 2001). They were measured by surveyors for recent births rather than reported by the mother. These data are therefore available for a shorter sample of births that occurred 3-5 years before the survey. To render the samples in the three rounds comparable, we restrict attention to the indicators of nutritional status of children aged 0-3 and exclude the states of Andhra Pradesh, Madhya Pradesh, Tamil Nadu, West Bengal, and Himachal Pradesh. The anthropometric data are standardized by age and gender and reported as z-scores. They are, by their nature, subject to survival selection.

Sample weights included in the surveys are used to obtain summary statistics that are representative for the all India population of mothers aged 15-49 at the time of the survey and their children. Regressions are also weighted using these weights. The sample we analyse changes because, for example, we drop births in the last month for the analysis of neonatal mortality but we drop births in the last five years when we investigate under-5 mortality. Alternatively, we are restricted to a shorter sample once we incorporate a set of regressors that are only available for recent years. All descriptive statistics are, unless otherwise stated, for the largest sample analysed, which is the sample of children fully exposed to neonatal mortality risk in the pooled sample.

\section{Descriptive Statistics}

This section first describes the religion differential in mortality and the way in which it varies with caste, age, gender, birth order, rural/urban and state location and

\footnotetext{
${ }^{5}$ For example, in the 1998 round, births that occur near the survey date will come representatively from mothers aged 15 to 49. However, births in earlier years, for example 1968, come disproportionately from women who gave birth early. This is because older mothers, for instance age 25 in 1968, were 55 in 1998 and so excluded from the sample by design.
} 
time. It also documents religion differentials in child nutritional status. It then describes the explanatory variables used in the analysis.

Table 1 goes about here.

\section{Neonatal, infant, and under-5 mortality}

Neonatal, infant and under-5 mortality are defined as the risk of dying between birth and the age of one month, one year, and five years, respectively. After dropping other religions, the sample of children analysed in this paper contains $84.58 \%$ Hindus and 14.42\% Muslims. Across births in the data, which span the period 1960-2006, average under-5 mortality is $15.93 \%$ amongst low caste Hindus, $12.59 \%$ amongst high caste Hindus, and $11.29 \%$ amongst Muslims. So Muslims have an advantage of 2.31\% points (17\% of baseline mortality risk) over all Hindus. Their advantage over low caste Hindus, at 4.64\%-points (29.14\%) is, unsurprisingly, greater than their advantage over high caste Hindus, which is $1.30 \%$-points (10.34\%). The latter is the real puzzle since upper caste Hindus are clearly better off than Muslims, whereas lower caste Hindus are, by many indicators, worse off (Government of India 2006). For neonatal [infant] mortality, the raw differential relative to low caste Hindus is 1.72 [3.06] \%-points, and relative to high caste Hindus it is 0.90 [1.31] \%-points.

In proportional terms, the mortality advantage with respect to high caste Hindus is decreasing with age of exposure (Table 1). As much as $70 \%$ of the difference between Muslims and high caste Hindus is established at birth, and the difference remains constant from infancy up until age five. In contrast, the Muslim advantage with respect to low caste Hindus is increasing in age of exposure, consistent with the higher SES of Muslims as compared with the lower castes.

Table 2 goes about here.

Averaging across communities, the under-5 survival advantage of boys over girls is $0.30 \%$-points. Disaggregating by community, we find that the all-India advantage of boys over girls is entirely driven by high caste Hindus amongst whom the differential is 0.53\%-points (Table 2). At birth, girls are, by nature, endowed with lower mortality risks. Their advantage is eroded with age. It is notable that while the Muslim advantage over low caste Hindus increases with age for both males and females, the Muslim advantage over high caste Hindus only increases with age for females. By age five, there is no gender difference in mortality rates amongst low caste Hindus, and girls exhibit an advantage of $0.08 \%$-points amongst Muslims. In Section 5.1 we shall see that these 
patterns persist after conditioning on other covariates. These facts are striking, and consistent with previous studies suggesting that higher caste Hindus exhibit greater son preference than lower caste Hindus (e.g. Drèze and Sen 1997). The survival data analysed here indicate that son preference amongst Muslims is lower than amongst Hindus and especially high caste Hindus. The Muslim advantage over upper caste Hindus is greater for girl survival, even if Muslims also show an advantage in boy survival. A lower degree of son preference amongst Muslims would not only influence survival chances for children of both genders by improving maternal health but it may further contribute to reducing the gender gap in survival. A lower degree of son-preference amongst Muslims (as compared with Hindus) is also apparent for other outcomes. For instance, Muslims exhibit a lower sex ratio (males/females) at birth (e.g. Barooah and Iyer 2006) and a smaller gender gap in educational enrolment (e.g. Bhalotra and Zamora forthcoming).

Table 3 goes about here.

The Muslim/high caste differential increases monotonically with birth-order, whereas the Muslim/low caste differential is nonlinear in birth order (Table 3). For neonatal mortality, however, after conditioning on covariates including maternal age at birth, it is only in the high caste group that the higher birth order child is significantly more vulnerable (Section 5.1). These patterns are consistent with Muslims having a higher taste for fertility.

Figure 1 goes about here.

The Muslim advantage is not a recent phenomenon, nor a diminishing one: see Figure 1, and also see Bhat and Zavier (2005). ${ }^{6}$ Annual averages of religion-specific mortality rates in survey data are subject to considerable sampling variation but taking decadal averages, we find a Muslim under-5 survival advantage of 1.91\%-points (8.9\% of the Hindu under-5 mortality rate) for births occurring during 1960-70 which decreased in absolute but not in proportional terms to 1.64\%-pts (16.24\%) in 1990-2001.

Table 4 goes about here.

Although the Muslim advantage over low caste Hindus is observed in both rural and urban sectors, disaggregation by sector reveals that Muslims only do significantly

\footnotetext{
${ }^{6}$ Their Table 6, p.389 reports the relevant means from the National Sample Surveys of 1963/4 and 1965/6, the Sample Registration Survey of 1979, Census 1981 and 1991, and the National Family Health Surveys (NFHS) of 1992/3 and 1998/9. In this paper, we use the NFHS surveys for 1992/3, 1998/9, and 2005/6, which contain information on births and child deaths over a span of 42 years. While data on mortality from surveys such as the NFHS can be subject to large sampling errors, SRS and Census data are not likely to suffer from this problem. The religion difference investigated here is apparent in these alternative data sets.
} 
better than upper caste Hindus in rural areas (Table 4). For this reason, we investigate the community differential for all-India as well as for the rural sample only. The Muslim advantage is not driven by special circumstances in any one region; it is apparent in 11 of 26 states for high caste Hindus and in 19 of 26 states for low caste Hindus (see Appendix Table 2). It is notable given our observations regarding community differences in gender preference that the Muslim advantage is least visible in the East and the Northeast, where Hindus have more matriarchal societies. Mortality rates vary substantially across the states, as does the size and the religion-composition of the state population. States with a higher proportion of Muslims appear to have lower under-5 mortality, although this may simply be a composition effect, with the lower mortality risks of Muslims driving the state average (Appendix Figure 1). States with a higher share of the country's Muslim population tend to have higher child mortality (Appendix Figure 2). The analysis to follow allows for compositional effects by including state fixed effects and trends.

\section{Nutritional Status}

We investigate two indicators of nutritional status for children aged 0-3, namely stunting and wasting. The first refers to height-for-age and indicates retardation of longterm growth, and the second refers to weight-for-height, which reflects contemporaneous insults to health (e.g. Martorell and Habicht 1986). Following WHO conventions, both indicators are defined as equal to one if the child is more than two standard deviations below the NCHS reference population median. ${ }^{7}$

Table 5 goes about here.

The average child's height-for-age and weight-for-height is below the reference population median in every community. Long-term health outcomes are particularly poor: the average low caste Hindu child is stunted, the average Muslim child is almost so, and even the average high caste Hindu child is 1.8 standard deviations below the reference median. Stunting rates are 52.0\%, 46.7\%, and 43.9\% respectively. Indian children fare better in terms of short-term health, with wasting rates at $20.3 \%, 17.3 \%$ and $16.9 \%$ (Table 5). The ranking of communities by stunting is consistent with their SES ranking; this is less clear for wasting. ${ }^{8}$ While Muslim children are more often stunted

\footnotetext{
${ }^{7}$ The U.S. National Center for Health Statistics (NCHS) standard, recommended by the World Health Organization (WHO) until recently, is the standard used to produce the z-scores provided in the first two NFHS waves.

${ }^{8}$ Regressions of disease probabilities on parental education and indicators for caste and religion suggest that Muslim children are significantly more prone to fever and, in urban areas, also more prone to diarrhoea
} 
than high caste Hindus, they are not more often wasted. Disaggregation by gender reveals no boy-girl differences amongst Muslims and low caste Hindus. However, amongst high caste Hindu, girls are shorter than boys (Table 6). This is a further indication of son preference being most marked in this relatively well-off group. Overall, Muslims have no large advantage in nutritional status that might directly explain their advantage in survival, although they do a bit better on wasting than the better off high caste Hindu group. We will investigate formally whether their better performance in weight-forheight poses a puzzle analogous to that concerning their better survival performance.

Table 6 goes about here.

To summarise, variation in community differences in survival by age of exposure suggests that they may be related to maternal health, and community differences in survival by birth order and gender indicate that at least some of the high caste Hindu disadvantage may stem from their stronger preference for sons and their weaker preference for high fertility (birth-order). Community differences in nutritional status are much smaller than community differences in survival. Muslims have no advantage with respect to stunting (height) and only a small advantage with respect to wasting (weight).

\section{The Independent Variables}

These include gender, birth order (whether born second, third, or fourth or above), birth month and birth year of the child, categories for the age of the mother at the birth of the child, rural/urban location of the household, a set of variables indicating the educational level of the mother and of the father, state dummies, and state-specific trends. This sort of specification is commonly used as a reduced form for the production of health outcomes; see Strauss and Thomas (1995), for example. Education may be thought to behave like technology in facilitating efficient use of inputs (Grossman 1972). It also represents socioeconomic status.

All-India means by religion are in Appendix Table 1. Some relevant community differences are summarised here. The sex ratio (male/female) at birth is lowest amongst Muslims, and this difference is marginally statistically significant in relation to high caste Hindus. As a consequence of higher Muslim fertility, a much larger share of Muslim children are of fourth or higher birth-order. High caste Hindu mothers and fathers tend to be more educated and the religion gap in education widens (in relative terms) with the

(in the two weeks before the survey) than are Hindu children; see Bhalotra (2007), from whom detailed results are available upon request. 
level of education. Averaging over the sample, Muslims are more educated than low caste Hindus. Muslims are more urbanised than (all) Hindus and, although not shown in these descriptive statistics, their poverty rate relative to Hindus is higher within urban areas than within rural areas (GOI, p. 153). In this way, inequality in SES between Muslims and Hindus appears to be lower in rural areas. The higher fertility of Muslims has the consequence that the average child is of higher birth order but it also exerts compositional effects associated with Muslim children being born, on average, to older mothers and later in (calendar) time (Figure 2). Overall, it seems clear that the standard (and especially, socioeconomic) predictors of mortality risk do not favour Muslims even if some compositional effects may favour them.

Figure 2 goes about here.

\section{Methods}

We estimate community specific reduced-form logits for mortality of the form

$$
\begin{gathered}
M_{\text {ist }}{ }^{*}=F\left(x_{\text {ist }}, \text { state }_{s}, \text { year }_{b} \text { state }^{*} \text { year }_{s t} ; \theta\right)+u_{\text {ist }} ; \\
M_{\text {ist }}=1 \text { if } M_{\text {ist }}{ }^{*}>0 \text { and } M_{\text {ist }}=0 \text { if } M_{\text {ist }}{ }^{*}<0
\end{gathered}
$$

$M_{i s t}$ denotes an indicator variable with value 1 if child $i$ born in year $t$ and state $s$ dies before the reference age and 0 otherwise. The reference age varies, being either one month (neonatal mortality), 12 months (infant mortality), or five years (under-5

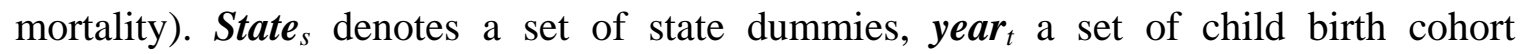
dummies, and state $^{*}$ year $_{\text {st }}$ a set of interaction terms between state dummies and a linear time trend that will control for state-time varying unobserved factors. The $u$ term denotes errors, assumed to be logistic, independent of the covariates, and independent for children in different villages (but not necessarily for children of the same village), and $\theta$ is a vector of parameters to be estimated. The vector $\boldsymbol{x}_{\text {ist }}$ contains exogenous or predetermined child and household characteristics described in Section $3 .^{9}$

Equation (1) is estimated separately for each of the three communities - low caste Hindus, high caste Hindus and Muslims. (see Section 5.1). The Hindu-Muslim gap is then decomposed to isolate the share due to differences in the independent variables

\footnotetext{
${ }^{9}$ These include maternal age at birth and birth order which are endogenous if fertility is endogenous. Bhalotra and van Soest (2008) describe a structural model that endogenises them and estimate it for neonatal mortality. Their model does not hold for infant or under-5 mortality, and it is not a priority to model structural effects of birth-spacing or fertility on mortality because we observe lower death risks amongst Muslim children despite their higher fertility and shorter birth-intervals. We nevertheless estimated their structural model for the case of neonatal mortality, and found qualitatively similar results to those presented here.
} 
across communities. This is done separately for low- and high caste Hindus (Section 5.2). We then explore extensions to the set of regressors in the mortality model and also investigate nutritional status rather than mortality (Section 6).

The decomposition uses an extension of the Blinder-Oaxaca technique that is appropriate for binary models (Fairlie 2006, Jann 2006). ${ }^{10}$ The average difference in the child mortality rate of the Hindu community $H$ and the Muslim community $M$ can be expressed as:

(2) $\bar{Y}^{H}-\bar{Y}^{M}=\left[\sum_{i=1}^{N^{H}} \frac{F\left(X_{i}^{H} \hat{\theta}^{H}\right)}{N^{H}}-\sum_{i=1}^{N^{M}} \frac{F\left(X_{i}^{M} \hat{\theta}^{H}\right)}{N^{M}}\right]+\left[\sum_{i=1}^{N^{M}} \frac{F\left(X_{i}^{M} \hat{\theta}^{H}\right)}{N^{M}}-\sum_{i=1}^{N^{M}} \frac{F\left(X_{i}^{M} \hat{\theta}^{M}\right)}{N^{M}}\right]$

with $\mathrm{H}$ indexing Hindus (either low- or high caste) and $\mathrm{M}$ indexing Muslims. $\bar{Y}^{J}(J=H, M)$ is the average probability of child death at the relevant age, $X^{J}$ is a row vector of independent variables, $\hat{\theta}^{J}$ is a vector of logit coefficient estimates including an intercept and $N^{J}$ is the number of observations. The first term in Eq. (2), is the mortality differential which we would see given the different characteristics of the two groups if Muslims behaved like Hindus (i.e. with parameters set equal to $\hat{\theta}^{H}$ for both groups). It is an estimate of the extent to which the gap would close if Hindus were assigned the characteristics of Muslims. We could just as well estimate this term forcing the responses of the two groups to be represented by the parameters of the Muslim equation, $\hat{\theta}^{\mathrm{M}}$. We present both estimates.

The second term in equation (2) picks up the residual or "unexplained" variation in mortality between the two groups. This may be interpreted as reflecting group-specific cultural norms, information, discount rates, attitudes or indeed any omitted variables.

The characteristics effect can be further decomposed into contributions of (groups of) covariates. For this purpose, it is necessary to match observations from both groups to obtain samples of similar sizes. Since decomposition results are potentially sensitive to the matching procedure, 100 low- or high caste Hindu samples were drawn randomly to be matched with the (smaller) Muslim sample, and the reported results are means across simulations. Moreover, when looking at the contribution of each variable, the order of regressors in the equation matters since the contribution of each characteristic is calculated conditional on the contribution of the previous ones (see Fairlie 2006, p.4).

\footnotetext{
${ }^{10}$ Despite the popularity of the Blinder-Oaxaca approach, there are few instances of decomposition exercises for non-linear models; exceptions include Fairlie (2006) and Bauer et al. (2007).
} 
This potential arbitrariness is minimised by randomising the ordering of the independent variables in each replication and reporting the average results thus obtained. The detailed decomposition is not sensitive to the choice of the omitted category for dummies included in the model (Oaxaca and Ransom 1999).]

\section{Results}

\subsection{Comparing determinants of child mortality amongst Muslims and Hindus}

Logit estimates for under-5 mortality are in Appendix Table 5 and the corresponding estimates for neonatal and infant mortality are in Appendix Table 4. Consistent with the biological advantage of newborn girls, they have a significant neonatal survival advantage in all three communities, and this is smallest amongst high caste Hindus. By the age of five, the advantage of girls is eroded in every community and, amongst high caste Hindus, it is turned around into a significant disadvantage. Mortality odds tend to be highest for first-borns and then to increase with birth order though less steeply for Muslims. It is notable that it is only for high caste Hindus that the neonatal odds are significantly higher at birth-order four and higher. Note that the estimated birth order effects are purged of the (correlated) effects of maternal age at birth since this is also included in the equation. These findings tie in with long-standing evidence of greater son-preference and lower desired fertility amongst high caste Hindus.

Mortality risk decreases monotonically with mother's age at birth for low caste Hindus and Muslims, except for Muslim infants of older (age 31-49) mothers, whose mortality risk is higher than in the 25-30 category. Amongst high caste Hindus, mortality odds decrease until age 25-30, before going up for older mothers. There is a tendency for children born in March and October/November, when temperatures are, on average, moderate, to face better survival chances. These effects are most clear in the low caste group, possibly indicating that vulnerability to the epidemiological environment is positively associated with poverty. The beneficial effects of parents' education increase with child age, consistent with an increasing role for environment and care in the survival technology. In general, the effects of paternal and maternal education are similar across the communities. As is commonly found, the coefficients on mother's education are somewhat larger than on fathers' education, possibly because mothers are the principal care-givers.

The disadvantage associated with living in a rural area is similar across communities although it is a bit smaller amongst high caste Hindus. State of residence 
matters more for Hindus than for Muslims. The year dummy coefficients, which are jointly significant in all regressions, suggest that low caste Hindus have experienced the smallest improvement in survival over time, and Muslims the largest. State-specific linear trends are jointly significant for the two Hindu groups at any reference age, but they are only significant for under-5 mortality amongst Muslims. Overall, there is significant between-community variation in state-level unobservables and in the rate of decline of mortality.

\subsection{Baseline Decomposition Results}

In this section, we present a decomposition of the mortality differential between Muslims and high caste Hindus and between Muslims and low caste Hindus for each mortality indicator. Estimates for under-5 mortality are in Tables 7 (whole sample) and 8 (rural sample). Estimates for neonatal and infant mortality are in Appendix Tables 6 and 7 respectively. The discussion will mostly focus on under-5 mortality where the paradox is most pronounced, but the essential conclusions are similar for neonatal and infant mortality. Results are benchmarked first on one parameter set $\left(\hat{\theta}^{H}\right)$ and then on the other $\left(\hat{\theta}^{M}\right)$. The results are sensitive to the choice of benchmark, but the overall conclusions of the analysis are not.

Table 7 goes about here.

\section{Muslims versus High Caste Hindus}

Differences in average characteristics between the communities predict a Muslim disadvantage relative to high caste Hindus of $0.36 \%$-points, explaining none of the $1.30 \%$ points advantage that Muslims exhibit. The characteristics that drive the predicted advantage of Hindus are their better parental education and their lower fertility, expressed as lower average birth order. The decomposition reveals that Muslims gain some advantage over Hindus on account of compositional factors. These are their greater urbanisation and two compositional factors associated with their higher fertility. First, the average Muslim child is born later in calendar time, which means it benefits from secular improvements in medical technology and institutional quality, and second, Muslim mothers are, on average, older at birth. ${ }^{11}$ State-specific trends also show some favour for

\footnotetext{
${ }^{11}$ These results are for the case where high caste Hindus are the reference group. Alternative results are in the Tables.
} 
Muslims. It is interesting that the higher fertility of Muslims exerts both direct and compositional effects on their relative chances, the first negative and the latter positive.

Overall, the decomposition shows that compositional advantages that accrue to Muslims on account of their location or their higher fertility are overwhelmed by their lower levels of education. This confirms that the substantial survival advantage that they exhibit remains, with the current (conventional) specification, a puzzle.

\section{Muslims versus Low Caste Hindus}

So as to detach omitted variables correlated with SES from religion and gain at least a casual understanding of the role of SES versus religion (i.e. unobservables associated with religion), we also compare Muslims with low caste Hindus. As discussed earlier, high caste Hindus are distinctly better off than Muslims but Muslims are, by many indicators, better off than low caste Hindus (Government of India 2006). The decomposition shows that only about a third of the Muslim advantage over low caste Hindus can be explained by the more favourable characteristics of Muslims. ${ }^{12}$

Table 8 goes about here.

\section{Isolating the Rural Sample}

Although the all-India decomposition showed that their greater urbanisation confers an advantage upon Muslims, we observed earlier that the Muslim advantage over high caste Hindus is only significant in the rural sample (Section 3). We therefore repeat the decomposition isolating rural households. In general, characteristics again completely fail to explain the Muslim advantage. The closest we get is that in the comparison with high caste Hindus that uses $\hat{\theta}^{H}$ rather than $\hat{\theta}^{M}$, birth-year, state effects and state trends are able to explain $10.6 \%$ of the Muslim advantage (Table 8).

So the paradox apparent in the raw data persists in that the better-off group does worse and Muslims appear to carry a favourable community fixed effect. In the next section, we put this assertion to the test by exploring extensions of the model, adding covariates that have been omitted so far to see if including them in the model diminishes the unexplained share of the Muslim advantage.

\footnotetext{
${ }^{12}$ In contrast, about $56 \%$ of the high caste Hindu advantage over low caste Hindus is explained by differences in the same covariates. Results are available upon request.
} 


\section{Extensions}

This section extends the analysis of mortality differences by adding controls for household wealth, state expenditure on health and development, indicators of health infrastructure at the village level and measures of maternal diet and health. It then investigates how well community differences in anthropometric indicators are explained by the more standard covariates.

\section{The Role of Wealth}

So far we have controlled for socioeconomic status using paternal and maternal education. These are likely to be strongly correlated with wealth but, if Muslims are systematically wealthier than Hindus for a given educational level, for instance, because they own more land, then we may not be picking up adequately the effect of wealth differentials. Although there is strictly no role for income or wealth in a health production function since, together with prices, these determine the level of inputs, income or wealth often appear in reduced form models of health (Strauss and Thomas 1995). Wealth is endogenous if omitted regressors such as ability and social connections influence both wealth and mortality or if mortality, by influencing the number of children and thus their costs, determines wealth. This is therefore not our preferred specification but we investigate it in order to be certain of the role of SES.

The NFHS contain information on a range of assets owned by households at the time of the survey- there are no retrospective data that record the evolution of household wealth over time that can be matched to the sequence of births in the retrospective mortality data. We therefore restrict the sample to children born no more than 10 years before the survey. The equation is estimated for under-5 mortality risk and so the sample is further restricted to remove children who have not had five years exposed to this risk. We use the first principal component of a set of assets as an indicator of wealth and include a set of dummies for the quartile of the wealth distribution that the individual household falls into.

Low and high caste Hindus face lower odds of dying if they are in the third or fourth quartiles of the wealth distribution, but there are no significant wealth effects for Muslims. The extended decomposition shows that wealth makes no contribution to the Muslim-Hindu mortality differential. And, overall, in this smaller, more recent sample, the overall contribution of characteristics to explaining the Muslim advantage is even more negative than in the full sample (Appendix Tables 8A and 8B). 


\section{State-level Macroeconomic Variables}

The baseline decomposition showed that state-time varying characteristics and (later) year of birth favour Muslim children, especially relative to low caste Hindus. It seems plausible that these reflect secular improvements in survival associated with the quality and spread of medical facilities, health awareness and overall prosperity. These same factors possibly also explain the higher mortality risk associated with rural areas. We investigate this for under-5 mortality by looking at the effects of (log) real per capita state expenditure on health and development projects, controlling for (log) real state income per capita and for rural and urban income inequality using Gini coefficients. ${ }^{13} \mathrm{We}$ add to equation (1), for under-5 mortality, a vector of these state-level macroeconomic variables. These data are only available for the 15 larger Indian states, which account for more than $95 \%$ of India's population, but result in us removing about $15.5 \%$ of observations because women in smaller states are over-sampled in the NFHS design. We find that state expenditure and income are insignificant but that rural inequality increases child mortality amongst Muslims and high caste Hindus. Together, the set of macroeconomic variables make no significant contribution to explaining the mortality differential (see Appendix Tables 9A and 9B).

\section{Village-level Infrastructure}

So changes in state-level expenditure and income do not explain much of the religion mortality differential, although state fixed effects and trends do. One potential explanation is that the state-level variables are too aggregative; we do not know how expenditure is distributed across villages with different concentrations of Hindus and Muslims. Another is that increases in expenditure do not translate into effective improvement in services because of absenteeism, corruption or absent complementary inputs. We therefore consider directly indicators of the availability of health facilities at the village level.

This information was only collected for rural areas and only in the first two rounds of the survey. Since the data in these two rounds turn out not to be strictly

\footnotetext{
${ }^{13}$ The effects of these variables are identified because the model includes state specific trends rather than interactions of state and time dummies.
} 
comparable, ${ }^{14}$ this extension uses only the rural sample from NFHS-2. As facilities are recorded for the time of the survey, we keep children born no more than six years before the interview. This makes it hard to analyse under- 5 mortality and allow 5 years exposure and so this analysis is conducted for neonatal and infant mortality (Appendix Tables 10A, 10B and 10C). Given the short time-span and some fairly small state-specific samples, we drop the state-specific time trends but, otherwise, the estimated model is as in equation (1), with added village regressors. In this sample, the Muslim survival advantage over high caste Hindus is not significant. However, even equal survival chances of these groups represent a "puzzle” because, as we will show below, differences in the characteristics of the two groups predict a Muslim disadvantage of up to $0.77 \%$ points (column 7).

The added village variables are the log of the village population, indicators for an all-weather road, a pharmacy, a mahilamandal (women's council), an anganwadi (community childcare centre), a primary health centre, a primary health sub-centre, a hospital, and dispensary or clinic. ${ }^{15}$ In both the neonatal and infant mortality specifications, the contributions of the village variables to explaining the differential are insignificant even if some are large in magnitude. Using more aggregated variables that are comparable in NFHS-1 and NFHS-2, and thus using both datasets, we similarly found no systematic evidence of differential access to health services after controlling for village size in Bhalotra, Valente and van Soest (forthcoming). We identified some factors that deepen the puzzle, such as the fact that Hindu women achieve better antenatal care and child immunization and some that help explain it, such as that Muslim mothers are more likely to seek treatment for diarrhoea, which is an important cause of child death. Potential reasons behind the failure of village infrastructure differences to explain any of the observed community differences in survival are (i) reverse causality, since areas with higher mortality may be specifically targeted by health authorities - e.g. Rosenzweig and Wolpin 1986; (ii) that access to facilities is largely disconnected from simple presence, for example, due to time-poverty (e.g. Bhalotra 2007) or staff absenteeism (e.g.

\footnotetext{
${ }^{14}$ For example, some unexpected patterns appear when comparing these data, such as a seeming reduction in the percentage of villages with a hospital or a clinic between NFHS-1 and NFHS-2.

${ }^{15}$ For neonatal mortality, these variables are only jointly significant in the Muslim regression. For infant mortality, the only individually significant variables are the presence of a mahilamandal, which is correlated with higher infant mortality amongst low caste Hindus, most likely due to reverse causality going from higher mortality to the establishment of this type of centre, and the availability of an anganwadi, which is correlated with lower mortality amongst Muslims.
} 
Chaudhury et al. 2006) and (iii) that quality of health facilities is weak - (e.g. World Bank 2004).

\section{Maternal health and diet}

As we have seen in Section 3, a large share of the survival advantage of Muslims is apparent at birth. This suggests a role for maternal health in explaining the puzzle. In Bhalotra et al. (forthcoming), we show that Muslim women in India are taller, have higher Body Mass Index (BMI), and are more likely to have a non-vegetarian diet than their Hindu counterparts. We also show that each of these factors is associated with improved survival chances for children.

Information on maternal height, BMI and diet is not available in NFHS-1, and so we focus here on the two latest NFHS rounds. Since maternal BMI and diet at the time of the survey are only relevant to children born in the few years preceding the survey, we restrict the sample to children born no more than six years before the interview. As in the case of village infrastructure, we drop the state-specific time trends but, otherwise, the estimated model is as in equation (1) for neonatal mortality, augmented with a dummy for vegetarian diet, a dummy for low BMI (i.e., BMI<18.5), its interaction with an indicator for being pregnant at the time of the interview, and the logarithm of maternal height (see Appendix Tables 12A and 12B). In this sample, the advantage of Muslim mothers in terms of height and BMI is only significant relative to low-caste Hindu mothers. We find that a vegetarian diet has an adverse impact on neonatal mortality for high-caste Hindus, and no significant impact in the other groups. Low BMI does not significantly affect neonatal mortality unless extreme, as indicated by the statistically significant effect of the interaction between the dummies for low maternal BMI and pregnancy. Taller mothers in every community are significantly less likely to see their children die in the first month of life (see Appendix Table 12A; Bhalotra and Rawlings 2008).

The decomposition of the community differential shows that maternal height explains some of the Muslim advantage over low-caste Hindus and a non-vegetarian diet explains some of their advantage over high-caste Hindus. Differences in BMI only reinforce the puzzle of the Muslim advantage over high-caste Hindus. We also estimated an alternative specification in which the only regressor added to our baseline model is maternal height. The advantage of this is that, as maternal height is time-invariant, we can now use the complete set of births as before. Pooling data from NFHS-2 and NFHS- 
3, we find that Muslim mothers have a height advantage over high and low caste Hindus. Analysing under-5 mortality, we find that this contributes to explaining some of the Muslim advantage, but the overall message from the decomposition is again that differences in characteristics add up to predict a high-caste Hindu advantage over Muslims, leaving the observed advantage of Muslims unexplained (see Appendix Tables 13A and 13B).

To summarise, controlling for household wealth, access to health services and public infrastructure, and maternal health and diet does not contribute much to understanding the puzzle of why mortality among children of Muslims is lower than among children of Hindus .

\section{Nutritional Status}

We noted in Section 3 that community differences in anthropometric deficits present a more mixed picture than for survival rates. We expect that nutritional status is correlated with survival although it is unclear whether it plays a causal role; see Almond et al. (2005) who suggest that mother-level heterogeneity is likely to be a strong confounder in the cross-sectional literature on birth weight. We cannot investigate this with our data because anthropometrics are only measured for children alive at the time of the survey. Indeed, there is survival selection in the data on heights and weights. To the extent that it is children with low potential height and weight who succumb early to mortality and are eliminated from the sample, we may expect greater similarity across communities in anthropometrics than we do in mortality rates.

The sample for this part of the analysis was described in Section 2, and stunting and wasting were defined and summarised in Section 3. The set of regressors is as in equation (1) although we do not include state-specific trends because this sample is relatively short, consisting of three years for each of the three survey rounds. The logit estimates are in Appendix Table 11.

Consider stunting first, for which the ranking of communities is consistent with their SES. The decomposition shows that between 75 and 94 per cent of the high caste Hindu advantage over Muslims is on account of differences in characteristics (Table 9).

Table 9 goes about here.

The characteristics that favour high caste Hindus are parental education, birth order and month of birth, and their advantage is only partly offset by a Muslim advantage on account of their urbanisation, birth year and state of residence. The Muslim advantage 
over low caste Hindus is more enigmatic. No more than $29 \%$ of the differential in stunting is explained by differences in characteristics. Mother's education, age at birth and birth year disadvantage lower caste Hindus and overwhelm factors that disadvantage Muslims, namely, higher birth order, distribution of month of birth and father's education. ${ }^{16}$ Thus there appear to be omitted variables specific to Muslim children that favour their height performance relative to low caste Hindus. When Muslims do worse, as is the case compared with high caste Hindus, then most of their disadvantage is explained. However, when they do better, as is the case relative to low caste Hindus, their advantage is unexplained. This is consistent with our earlier finding that the Muslim community has some unobservable traits that favour health.

Table 10 goes about here.

Now consider wasting, the indicator on which Muslims do relatively well. Although wasting amongst Muslims is lower by $0.40 \%$-points, differences in characteristics suggest it should be higher by up to 0.56\%-points, compared with high caste Hindus, who are favoured again by better parental education and lower birth order. Muslims do better than the low caste group but at most $20 \%$ of their advantage is explained by characteristics and this rests upon unobservables captured by the state dummies (Table 10). So Muslims show an unexplained advantage relative to both castes of Hindus in avoiding low weight-for-age just as they do in avoiding mortality. The summary results are arrayed for our many alternative specifications in Table 11.Table 11 goes about here.

\section{Conclusion}

Our initial specification examined the contribution to the community survival differential of parental education, family demographics and state and cohort-specific unobservables for three indicators of survival and two indicators of nutritional status. For survival, we further explored the contribution of asset ownership, state macroeconomic variables, rural health services and infrastructure, and maternal health and diet. We find that, in general, none of the Muslim advantage over high caste Hindus can be explained while, typically, less than half of their advantage over low caste Hindus can be explained by differences in characteristics.

\footnotetext{
${ }^{16}$ In this short sample, Muslim fathers are less educated than low caste Hindus. This is a reflection of the more rapid educational progress of low caste as compared with Muslim men over time. In contrast, Muslim women have advanced fairly rapidly (see Deolalikar 2008).
} 
The essence of the paradox that this paper highlights is that, when we consider averages by religious community in India, then the commonly found positive association of socioeconomic status and survival breaks down. Our decomposition of the community differential suggests that the effects of SES are overwhelmed by some unobservable trait owned by the lower SES group. ${ }^{17}$ Correlates of religion that may plausibly influence survival without exhibiting a strong positive correlation with SES include diet, attitudes to women's work, personal hygiene, political clout or social norms and networks. Some of these effects may be better cast as historical, cultural or biological factors in that they are unrelated to religious belief per se even if they have gelled around a community that is identified by its religion.

Some clues emerged from profiling the religion differential by age, gender and birth order (Section 3). More than two-thirds of the survival advantage of Muslims over high-caste Hindus is apparent at birth and, in proportional terms, it decreases between the age of one and five. This suggests that explanations of the differential may have more to do with maternal health, delivery and early feeding practices and less to do with access to resources or public services post-infancy. If we argue that maternal health is key, then we must also argue that there are aspects of maternal health that are not directly linked to their SES, or else controlling for parental education and asset ownership would have explained at least part of the differential.

Scattered evidence suggests that there are. For example, a lower degree of son preference amongst Muslim as compared with Hindu households (see Section 3) may have meant that Muslim mothers received a more equal share of household resources in their own childhoods. This is suggested to hold in Basant (2007). Trends in adult height for birth cohorts 1956-86 are also consistent with this assertion, given evidence that childhood conditions have a profound influence on adult height (Bozzoli et al. forthcoming): Over this period, Muslim women gained height significantly faster than Hindu women, while Muslim men grew more slowly than Hindu men (Bhalotra 2008). Alternatively, better maternal health amongst Muslims may be the result of their having a more balanced or non-vegetarian diet (Section 6), or of their being less likely to work during and just after pregnancy (Bhalotra et al. forthcoming). A third factor that may favour maternal health amongst Muslims despite their lower SES is their stronger kinship structures which, in part, have to do with a greater prevalence of endogamy in this

\footnotetext{
${ }^{17}$ Read Muslims relative to high caste Hindus, although comparisons of Muslims with low caste Hindus reinforce this conclusion.
} 
community. This is associated with lower marriage payments and the perception of the girl child as less of a burden, as well as with the availability of extended care for the mother and the newborn child from the natal family (e.g. Robinson 2007). It may also make for better information sharing amongst women, and stronger insurance networks.

In Bhalotra et al. (forthcoming), we show that antenatal care practices are less favourable to child survival amongst Muslims, and that Muslim women give birth outside medical facilities more often than their Hindu counterparts, thus reinforcing the puzzle. On the other hand, in the same study we find that Muslim women tend to put the baby to the breast sooner after birth. This may contribute to explaining the Muslim survival advantage. Differences in maternal BMI and vegetarian diet at the time of the survey, as well as in maternal height, make only a small contribution to explaining the puzzle (Section 6), but further research using alternative measures of mother's health and maternal and child diet, in particular during pregnancy and in the immediate postnatal period (including breastfeeding), may shed more light on the conundrum.

Although there is no evidence on which way this goes, it is worth flagging a potential role here for differences in foetal survival. Since the evidence points to the importance of maternal health, it is plausible that Muslims not only have (visibly) better survival chances of newborn children but that they experience, for the same reasons, (invisibly) lower risks of foetal death. This would contribute to explaining the higher fertility of Muslim women which, so far, has been explained in terms of higher desired fertility and greater aversion to the use of contraception. However, selection may turn this around. If poverty (SES) dominates in the risk of foetal loss and Muslims are in fact more likely than upper caste Hindus to suffer it then, assuming that it is the frailest children who die in utero; the average live birth amongst Muslims will tend to be less frail and more likely to survive. This may contribute to explaining the higher survival chances of Muslim children (which is, by convention, measured as a fraction of live births).

There is a clear agenda for future research in this area. Differences between communities in maternal health and in attitudes to pregnancy may create differences in foetal death risk, with consequences for observed differences in both childhood mortality and fertility. This has not been previously investigated. It would be useful for policy if we could separate inalienable characteristics from behaviours (like labour supply or treatment of sons versus daughters) that are more transferable and, related, if we could identify the extent to which information or risk-sharing networks operate along religion lines (e.g. Munshi and Myaux (2006) find that social change emerges from separate 
social interaction amongst Muslims and Hindus in rural Bangladesh). It would also be useful to map the geographic distribution of low and high caste Hindus and Muslims at the village level, to indicate, for example, the degree of residential segregation of the communities. This may have implications for the provision of public services (Alesina et al. 1999). Finally, it would be instructive to directly consider the political economy of public provision and the extent to which it is influenced by caste and religion of both elected leaders and constituency members (e.g. Pande 2003). 


\section{References}

Alesina, Alberto, Reza Baqir and William Easterly (1999), "Public Goods and Ethnic

Divisions,” Quarterly Journal of Economics, November 1999, 114: 1243-84.

Almond, Douglas, Kenneth Chay and David Lee. 2005. "The Costs of Low Birth Weight". Quarterly Journal of Economics 120(3): 1031-1083.

Barooah, Vani K. and Sriya Iyer. 2005. "Vidya, Veda and Varna: The Influence of Religion and Caste on Education in Rural India". Journal of Development Studies 41(8): 1369-1404.

Bauer, Thomas, Silja Golhmann and Mathias Sinning. 2007. "Gender Differences in Smoking Behavior". Health Economics 16:895-909.

Basant, Rakesh. 2007. "Social, Economic and Educational Conditions of Indian Muslims". Economic and Political Weekly 42(10): 828-832.

Bhalotra, Sonia. 2007. "Fatal Fluctuations? Cyclicality in Infant Mortality in India, IZA Discussion Paper 3086". Institute for the Study of Labor (IZA), Bonn.

Bhalotra, Sonia. 2008. "Gender Differentials Again: Evidence from Cohort Profiles of the Heights of Men and Women". Mimeograph, University of Bristol.

Bhalotra, Sonia, Arnim Langer, Frances Stewart and Bernarda Zamora. 2008. "Persistent Muslim/Hindu Inequalities in India". Mimeograph, CRISE, University of Oxford.

Bhalotra, Sonia and Sam Rawlings. 2008. "The Intergenerational Transmission of Health in Developing Countries". Mimeograph, University of Bristol.

Bhalotra, Sonia, Christine Valente and Arthur van Soest. Forthcoming. "Religion and Childhood Death in India" In Handbook of Muslims in India, ed. A Sharif and R Basant, Delhi: Oxford University Press.

Bhalotra, Sonia and Arthur van Soest. 2008. "Birth-Spacing, Fertility and Neonatal Mortality in India: Dynamics, Frailty, and Fecundity". Journal of Econometrics 143(2): 274-290.

Bhalotra, Sonia and Bernarda Zamora. Forthcoming. "Social Divisions in Education in India" In Handbook of Muslims in India, ed. A. Sharif and R. Basant, Delhi: Oxford University Press.

Bhat, Mari and Francis Zavier. 2005. "Role of Religion in Fertility Decline: The Case of Indian Muslims". Economic and Political Weekly 40(5): 385-402. 
Bhaumik, Sumon K. and Manisha Chakrabarty. 2006. "Earnings Inequality in India: Has the Rise of Caste and Religion Based Politics in India Had an Impact?" Working Paper 819, William Davidson Institute, University of Michigan.

Bozzoli, C, Angus Deaton and C Quintana-Domeque. Forthcoming. "Adult Height and Childhood Disease". Demography.

Census of India. 2001. "Fertility Tables, available online at http://www.censusindia.gov.in/Data_Products/Data_Highlights/Data_Highlights_link/dat a_highlights_F9_F10.pdf."

Chaudury, Nazmul, Jeffrey Hammer, Michael Kremer, Karthik Muralidharan and Halsey Rogers. 2006. "Missing in Action: Teacher and Health Worker Absence in Developing Countries". Journal of Economic Perspectives 20(1): 91-116.

Cutler, D, Angus Deaton and A Lleras-Muney. 2006. "The Determinants of Mortality". Journal of Economic Perspectives 20(3): 97-120.

Deolalikar, Anil B. Forthcoming, How Do Indian Muslims Fare on Social Indicators? In Handbook of Muslims in India, ed. A Sharif and R Basant, Delhi: Oxford University Press.

Drèze, Jean and Amartya Sen. 1997. Indian Development: Selected Regional Perspectives, Oxford: Clarendon Press.

Fairlie, Robert. 2006. "An Extension of the Blinder-Oaxaca Decomposition Technique to Logit and Probit Models". IZA Discussion Paper No. 1917, Institute for the Study of Labor (IZA), Bonn.

Fryer, R.G. and S.D Levitt. 2004. "Understanding the Black-White Test Score Gap in the First Two Years of School". Review of Economics and Statistics 86: 447-464.

Fuchs, Victor R. 2004. "Reflections on the Socio-Economic Correlates of Health". Journal of Health Economics 23: 653-661.

Government of India. 2006. "Social, Economic and Educational Status of the Muslim Community of India: A Report. Prime Minister’s High Level Committee".

Grossman, Michael. 1972. The Demand for Health: A Theoretical and Empirical Investigation. New York: Columbia University Press for the National Bureau of Economic Research.

Guinnane, Timothy. 2005. "The Fertility Transition in Europe”. European Society of Population Economics, keynote address.

IIPS. 1995. "National Family Health Survey (MCH and Family Planning), India 199293." International Institute for Population Sciences (IIPS), Mumbai. 
IIPS and ORC Macro. 2000. "National Family Health Survey (NFHS-2) 1998-99 India". International Institute for Population Sciences (IIPS), Mumbai.

IIPS and Macro International. 2007. "National Family Health Survey (NFHS-3), India 2005-06". International Institute for Population Sciences (IIPS), Mumbai.

Jann, Ben. 2006. "Fairlie: Stata Module to Generate Nonlinear Decomposition of Binary Outcome Differentials. Available from http://ideas.repec.org/c/boc/bocode/s456727.html. Klasen, Stephan. 2003. "Malnourished and Surviving in South Asia, Better Nourished and Dying Young in Africa: What Can Explain this Puzzle?" In Measurement and Assessment of Food Deprivation and Undernutrition, ed. FAO, Rome: FAO.

Martorell, Reynaldo and Jean-Pierre Habicht. 1986. "Growth in Early Childhood in Developing Countries" In Human Growth: A Comprehensive Treatise. Volume 3: Methodology and Ecological, Genetic, and Nutritional Effects on Growth, 2nd ed., ed. Frank Falkner and J.M. Tanner, New York: Plenum Press.

Micklewright, John and Suraiya Ismail. 2001. "What Can Child Anthropometrics Reveal About Living Standards and Public Policy: An illustration from Central Asia”, Review of Income and Wealth, March, Vol. 47 Issue 1, p 65-80.

Munshi, Kaivan and Jacques Myaux. 2006. “Social Norms and the Fertility Transition.” Journal of Development Economics 80(1):1-38.

Oaxaca, Ronald and Michael Ransom. 1999. "Identification in Detailed Wage Decompositions". The Review of Economics and Statistics 81(1): 154-157.

Pande, Rohini. 2003. “Can Mandated Political Representation Provide Disadvantaged Minorities Policy Influence? Theory and Evidence from India”. American Economic Review, Vol. 93(4), pp. 1132-1151, September.

Robinson, Rowena. 2007. "Indian Muslims: The Varied Dimensions of Marginality". Economic and Political Weekly 42(10): 839-843.

Rogers, Richard G., Robert A. Hummer and Charles B. Nam. 2000. Living and Dying in the USA. Behavioral, Health, and Social Differences in Adult Mortality. New York: Academic Press.

Rosenzweig, Mark and Kenneth Wolpin. 1986. "Evaluating the Effects of Optimally Distributed Public Programs: Child Health and Family Planning Interventions". American Economic Review 76: 470-482.

Shariff, Abusaleh. 1995. "Socio-Economic and Demographic Differentials between Hindus and Muslims in India". Economic and Political Weekly 30(46): 2947-2953. 
Straus, John and Duncan Thomas. 1995. "Human Resources: Empirical Models of Household Decisions" In Handbook of Development Economics, Volume IIIA, ed. J.R. Behrman and T.N. Srinivasan, Amsterdam: North Holland.

Varshney, Ashutosh. 2002, Ethnic Conflict and Civic Life: Hindus and Muslims in India, Yale University Press.

Wilson, Deborah, Simon Burgess and Adam Briggs. 2005. "The Dynamics of School Attainment of England's Ethnic Minorities". Working Paper 05/130, CMPO, University of Bristol.

World Bank. 2004. World Bank Development Report: Making Services Work for Poor People. World Bank, Washington DC. 


\section{$\underline{\text { Tables }}$}

Table 1: Mortality Rates and Differentials by Community

\begin{tabular}{|c|c|c|c|c|c|}
\hline & $\begin{array}{c}\text { (1) } \\
\text { Low Caste } \\
\%\end{array}$ & $\begin{array}{c}(2) \\
\text { Differential } \\
\text { LC-M } \\
\%-p o i n t s \\
\text { (as \% of (1)) }\end{array}$ & $\begin{array}{c}\text { (3) } \\
\text { High Caste } \\
\%\end{array}$ & $\begin{array}{c}(4) \\
\text { Differential } \\
\text { HC-M } \\
\% \text {-points } \\
\text { (as \% of (3)) }\end{array}$ & $\begin{array}{c}\text { (5) } \\
\text { Muslim } \\
\%\end{array}$ \\
\hline Neonatal & 6.79 & $\begin{array}{c}1.72 \\
(25.30)\end{array}$ & 5.98 & $\begin{array}{c}0.90 \\
(15.12)\end{array}$ & 5.08 \\
\hline Infant & 11.03 & $\begin{array}{c}3.06 \\
(27.69)\end{array}$ & 9.29 & $\begin{array}{c}1.31 \\
(14.08)\end{array}$ & 7.98 \\
\hline Under-5 & 15.93 & $\begin{array}{c}4.64 \\
(29.14)\end{array}$ & 12.59 & $\begin{array}{c}1.30 \\
(10.34)\end{array}$ & 11.29 \\
\hline
\end{tabular}

LC is low-caste Hindu (SC and ST), HC is high-caste Hindu, and M is Muslim. Sample of children fully exposed to the relevant mortality risk and for whom caste status is known ( $\mathrm{N}=$ 653,496 for neonates, $\mathrm{N}=629,058$ for infants, $\mathrm{N}=522,377$ for under5s). All differentials are significant at the $1 \%$ level.

Table 2: Mortality Rates by Community and Gender

\begin{tabular}{llccc}
\hline \multirow{2}{*}{ Male } & Low Caste & 7.41 & Infant & Under-5 \\
& High Caste & 6.40 & 11.33 & 15.93 \\
& Muslim & 5.60 & 9.42 & 12.34 \\
& & & 8.26 & 11.33 \\
Female & Low Caste & 6.13 & & \\
& High Caste & 5.52 & 9.15 & 15.94 \\
& Muslim & 4.51 & 7.68 & 12.87 \\
\hline
\end{tabular}

See notes to Table 1 . For neonates, the female sample size is 313,461 and the male sample size is 340,035 .

Table 3: Mortality Rates by Community and Birth Order

\begin{tabular}{clccc}
\hline Birth order & & Neonatal & Infant & Under-5 \\
\hline 1 & Low Caste & 8.63 & 12.64 & 16.67 \\
& High Caste & 7.14 & 9.94 & 11.74 \\
& Muslim & 6.62 & 9.19 & 11.21 \\
& & & & \\
& Low Caste & 6.24 & 10.44 & 15.36 \\
& High Caste & 5.11 & 7.98 & 10.25 \\
& Muslim & 4.53 & 7.20 & 9.78 \\
& & & & 14.64 \\
& Low Caste & 5.43 & 9.38 & 10.58 \\
& High Caste & 4.96 & 8.01 & 9.31 \\
& Muslim & 4.24 & 6.82 & 16.50 \\
& & & & 14.45 \\
& Low Caste & 6.36 & 11.01 & 11.42 \\
\hline
\end{tabular}


See notes to Table 1. For neonates, sample sizes are, respectively, 197,952; 166,382; 117,490 and 171,672 for first-, second-, third- and fourth and above birth order. All differentials are significant at the $1 \%$ level, except for the high-caste Hindu differential for first-born children (p-value=0.0226).

Table 4: Mortality Rates by Community and Rural/Urban Location

\begin{tabular}{clccc}
\hline \multirow{2}{*}{ Urban } & Low Caste & Neonatal & Infant & Under-5 \\
& High Caste & 5.13 & 8.25 & 11.48 \\
& Muslim & 4.32 & 6.54 & 8.51 \\
& & 3.97 & 6.40 & 8.84 \\
\multirow{5}{*}{ Rural } & & & \\
& Low Caste & 7.13 & 11.61 & 16.86 \\
& High Caste & 6.55 & 10.24 & 14.03 \\
& Muslim & 5.68 & 8.84 & 12.66 \\
\hline
\end{tabular}

See notes to Table 1. For neonates, sample sizes are 209,999 for urban areas and 443,497 for rural areas. All differentials are significant at the $1 \%$ level or below except for the Muslim/high-caste differentials in urban areas, which are not significant at any usual level. 
Table 5: Malnutrition Rates by Community

\begin{tabular}{|c|c|c|c|c|c|c|c|c|}
\hline & $\begin{array}{l}\text { Low- } \\
\text { caste } \\
\text { Hindu }\end{array}$ & & $\begin{array}{c}\text { p-value } \\
\text { of } \\
\text { Wald } \\
\text { test } \\
\text { LC-M }\end{array}$ & $\begin{array}{l}\text { High- } \\
\text { caste } \\
\text { Hindu }\end{array}$ & & $\begin{array}{c}\text { p-value } \\
\text { of } \\
\text { Wald } \\
\text { test } \\
\text { HC-M }\end{array}$ & Muslim & \\
\hline & mean & s.d. & & mean & s.d. & & mean & s.d. \\
\hline Height-for-age: & & & & & & & & \\
\hline s.d. from the reference median (z) & -2.054 & 1.588 & 0.0003 & -1.788 & 1.566 & 0.0000 & -1.927 & 1.650 \\
\hline \% stunted ( $\mathrm{z}<2$ s.d. below median) & 52.0 & & 0.0000 & 43.9 & & 0.0030 & 46.7 & \\
\hline Weight-for-height: & & & & & & & & \\
\hline s.d. from the reference median (z) & -1.101 & 1.120 & 0.0000 & -1.002 & 1.094 & 0.8192 & -0.998 & 1.091 \\
\hline$\%$ wasted ( $\mathrm{z}<2$ s.d. below median) & 20.3 & & 0.0000 & 17.3 & & 0.5316 & 16.9 & \\
\hline Number of children & 10485 & & & 25114 & & & 7613 & \\
\hline
\end{tabular}

LC is low-caste Hindu (SC and ST), HC is high-caste Hindu, and M is Muslim. Sample consists of children no more than 36 months old for states where height and weight were measured in all NFHS rounds, i.e., all states except Andhra Pradesh, Madhya Pradesh, Tamil Nadu, West Bengal, and Himachal Pradesh. Top percentile of height-for-age and weightfor-height distributions dropped to remove outliers. Reference population is the National Center for Health Statistics (NCHS) standard.

Table 6: Malnutrition Rates by Community and Gender

\begin{tabular}{|c|c|c|c|}
\hline & & Height-for-age & Weight-for-height \\
\hline \multirow[t]{5}{*}{ Boys } & Low Caste & -2.062 & -1.120 \\
\hline & & [0.005] & {$[0.0001]$} \\
\hline & High Caste & -1.768 & -1.008 \\
\hline & & {$[0.000]$} & [0.808] \\
\hline & Muslim & -1.937 & -1.001 \\
\hline \multirow[t]{5}{*}{ Girls } & Low Caste & -2.045 & -1.082 \\
\hline & & {$[0.007]$} & {$[0.005]$} \\
\hline & High Caste & -1.811 & -0.996 \\
\hline & & {$[0.014]$} & [0.922] \\
\hline & Muslim & -1.917 & -0.993 \\
\hline
\end{tabular}

These are z-scores defined as standard deviations from the median of the reference population. See also notes to Table 5. P-values of a Wald test for the significance of the difference compared to Muslim children are in brackets. 
Table 7: Decomposition of the Hindu-Muslim Under-5 Mortality Differential, Whole Sample.

\begin{tabular}{|c|c|c|c|c|c|c|c|c|c|c|c|c|}
\hline \multirow{3}{*}{ Benchmark } & \multicolumn{6}{|c|}{ Low-caste/Muslim } & \multicolumn{6}{|c|}{ High-caste/Muslim } \\
\hline & $\mathrm{LC}$ & & & $\mathrm{M}$ & & & $\mathrm{HC}$ & & & $\mathrm{M}$ & & \\
\hline & \%-point & $\begin{array}{c}\text { \% of } \\
\bar{Y}^{H}-\bar{Y}^{M}\end{array}$ & z-stat & \%-point & $\begin{array}{c}\text { \% of } \\
\bar{Y}^{H}-\bar{Y}^{M}\end{array}$ & z-stat & \%-point & $\begin{array}{c}\text { \% of } \\
\bar{Y}^{H}-\bar{Y}^{M}\end{array}$ & z-stat & \%-point & $\begin{array}{c}\text { \% of } \\
\bar{Y}^{H}-\bar{Y}^{M}\end{array}$ & z-stat \\
\hline $\bar{Y}^{H}-\bar{Y}^{M}$ & 4.65 & 100.00 & & 4.65 & 100.00 & & 1.34 & 100.00 & & 1.34 & 100.00 & \\
\hline Explained $^{\mathrm{a}}$ & 1.56 & 33.62 & & 1.25 & 26.83 & & -0.36 & -26.67 & & -0.37 & -27.86 & \\
\hline Unexplained $^{\mathrm{b}}$ & 3.09 & 66.38 & & 3.40 & 73.17 & & 1.70 & 126.67 & & 1.71 & 127.86 & \\
\hline $\begin{array}{l}\text { Detailed } \\
\text { contributions }\end{array}$ & & & & & & & & & & & & \\
\hline Gender & 0.00 & 0.00 & -0.06 & 0.00 & 0.00 & 0.00 & 0.00 & -0.14 & -1.66 & 0.00 & -0.01 & -0.10 \\
\hline Birth order & -0.22 & -4.71 & -5.59 & -0.15 & -3.17 & -3.14 & -0.36 & -26.75 & -10.81 & -0.24 & -18.02 & -4.27 \\
\hline Birth month & 0.00 & -0.05 & -0.26 & 0.01 & 0.18 & 0.64 & -0.01 & -0.70 & -1.27 & 0.00 & 0.32 & 0.29 \\
\hline Mother's age at birth & 0.43 & 9.25 & 8.08 & 0.28 & 6.00 & 4.76 & 0.09 & 6.65 & 2.69 & 0.01 & 0.90 & 0.23 \\
\hline Father’s education & 0.16 & 3.48 & 6.81 & 0.14 & 3.02 & 4.95 & -0.57 & -42.57 & -14.59 & -0.39 & -29.01 & -5.52 \\
\hline Mother's education & 0.30 & 6.53 & 6.71 & 0.30 & 6.44 & 6.36 & -0.34 & -25.34 & -14.19 & -0.32 & -23.83 & -5.47 \\
\hline Rural & 0.56 & 12.09 & 7.14 & 0.43 & 9.34 & 5.54 & 0.25 & 18.62 & 8.24 & 0.24 & 17.90 & 5.25 \\
\hline Birth year & 0.05 & 1.07 & 0.71 & 0.04 & 0.94 & 0.13 & 0.43 & 31.85 & 4.66 & 0.70 & 52.00 & 1.80 \\
\hline State & -1.06 & -22.88 & -2.29 & -0.90 & -19.28 & -1.33 & -0.05 & -3.85 & -0.24 & 0.01 & 0.66 & 0.02 \\
\hline State trends & 1.34 & 28.86 & 2.99 & 1.09 & 23.37 & 1.47 & 0.21 & 15.72 & 0.86 & -0.38 & -28.65 & -0.62 \\
\hline
\end{tabular}

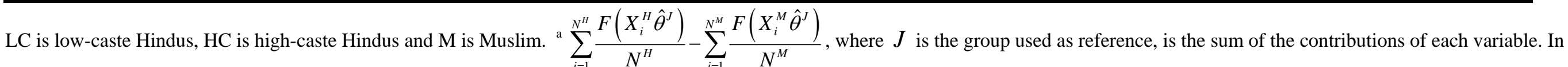

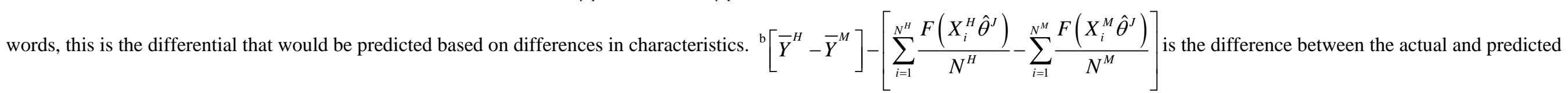
differentials. 
Table 8: Decomposition of the Hindu-Muslim Under-5 Mortality Differential, Rural Sample Only.

\begin{tabular}{|c|c|c|c|c|c|c|c|c|c|c|c|c|}
\hline \multirow{3}{*}{ Benchmark } & \multicolumn{6}{|c|}{ Low-caste/Muslim } & \multicolumn{6}{|c|}{ High-caste/Muslim } \\
\hline & $\mathrm{LC}$ & & & $\mathrm{M}$ & & & $\mathrm{HC}$ & & & $\mathrm{M}$ & & \\
\hline & \%-point & $\begin{array}{c}\text { \% of } \\
\bar{Y}^{H}-\bar{Y}^{M}\end{array}$ & z-stat & \%-point & $\begin{array}{c}\text { \% of } \\
\bar{Y}^{H}-\bar{Y}^{M}\end{array}$ & z-stat & \%-point & $\begin{array}{c}\text { \% of } \\
\bar{Y}^{H}-\bar{Y}^{M}\end{array}$ & z-stat & \%-point & $\begin{array}{c}\text { \% of } \\
\bar{Y}^{H}-\bar{Y}^{M}\end{array}$ & z-stat \\
\hline$\overline{\bar{Y}}^{H}-\bar{Y}^{M}$ & 4.25 & 100.00 & & 4.25 & 100.00 & & 1.44 & 100.00 & & 1.44 & 100.00 & \\
\hline Explained $^{\mathrm{a}}$ & 1.28 & 30.21 & & 0.54 & 12.64 & & 0.15 & 10.59 & & -0.56 & -39.01 & \\
\hline $\begin{array}{l}\text { Unexplained }^{\mathrm{b}} \\
\text { Detailed } \\
\text { contributions }\end{array}$ & 2.96 & 69.79 & & 3.71 & 87.36 & & 1.29 & 89.41 & & 2.00 & 139.01 & \\
\hline Gender & 0.00 & 0.00 & -0.15 & 0.00 & -0.01 & -0.11 & 0.00 & -0.10 & -0.77 & 0.00 & -0.03 & -0.24 \\
\hline Birth order & -0.20 & -4.77 & -4.65 & -0.12 & -2.79 & -2.25 & -0.23 & -16.22 & -7.16 & -0.15 & -10.31 & -2.67 \\
\hline Birth month & 0.01 & 0.24 & 1.11 & 0.04 & 0.98 & 2.27 & 0.00 & 0.12 & 0.22 & 0.04 & 2.66 & 1.99 \\
\hline Mother's age at birth & 0.33 & 7.72 & 5.61 & 0.21 & 5.03 & 3.07 & -0.03 & -1.90 & -0.65 & -0.09 & -6.25 & -1.32 \\
\hline Father’s education & 0.09 & 2.12 & 4.67 & 0.11 & 2.69 & 3.39 & -0.53 & -37.09 & -12.12 & -0.49 & -34.01 & -5.44 \\
\hline Mother’s education & 0.21 & 4.97 & 4.62 & 0.23 & 5.31 & 4.36 & -0.23 & -15.98 & -9.76 & -0.24 & -16.49 & -3.47 \\
\hline Rural & 0.00 & 0.00 & & 0.00 & 0.00 & & 0.00 & 0.00 & & 0.00 & 0.00 & \\
\hline Birth year & 0.07 & 1.58 & 0.73 & 0.15 & 3.62 & 0.24 & 0.57 & 39.74 & 4.60 & 1.18 & 81.72 & 1.60 \\
\hline State & -0.30 & -7.06 & -0.46 & -0.86 & -20.29 & -0.76 & 0.38 & 26.57 & 1.04 & 0.06 & 3.83 & 0.07 \\
\hline State trends & 1.09 & 25.58 & 1.74 & 0.77 & 18.22 & 0.59 & 0.22 & 15.56 & 0.54 & -0.86 & -60.01 & -0.74 \\
\hline
\end{tabular}

See notes to Table 7. 
Table 9: Decomposition of the Hindu-Muslim Stunting Differential

\begin{tabular}{|c|c|c|c|c|c|c|c|c|c|c|c|c|}
\hline \multirow{3}{*}{ benchmark } & \multicolumn{6}{|c|}{ Low-caste/Muslim } & \multicolumn{6}{|c|}{ High-caste/Muslim } \\
\hline & \multirow{2}{*}{$\frac{\text { LC }}{\text { \%-point }}$} & \multicolumn{5}{|c|}{$\mathrm{M}$} & \multirow{2}{*}{$\frac{\mathrm{HC}}{\text { \%-point }}$} & \multicolumn{5}{|c|}{$\mathrm{M}$} \\
\hline & & $\begin{array}{c}\text { \% of } \\
\bar{Y}^{H}-\bar{Y}^{M}\end{array}$ & z-stat & \%-point & $\begin{array}{c}\text { \% of } \\
\bar{Y}^{H}-\bar{Y}^{M}\end{array}$ & z-stat & & $\begin{array}{c}\text { \% of } \\
\bar{Y}^{H}-\bar{Y}^{M}\end{array}$ & z-stat & \%-point & $\begin{array}{c}\text { \% of } \\
\bar{Y}^{H}-\bar{Y}^{M}\end{array}$ & z-stat \\
\hline $\bar{Y}^{H}-\bar{Y}^{M}$ & 5.25 & 100.0 & & 5.25 & 100.0 & & -2.81 & 100.00 & & -2.81 & 100.00 & \\
\hline Explained $^{\mathrm{a}}$ & 1.53 & 29.15 & & 1.23 & 23.43 & & -2.63 & 93.60 & & -2.11 & 75.25 & \\
\hline Unexplained $^{\mathrm{b}}$ & 3.72 & 70.85 & & 4.02 & 76.57 & & -0.18 & 6.40 & & -0.70 & 24.75 & \\
\hline Detailed contributions ${ }^{c}$ & & & & & & & & & & & & \\
\hline Gender & 0.00 & 0.00 & -0.02 & 0.00 & 0.08 & 0.33 & -0.01 & 0.53 & -1.80 & -0.01 & 0.18 & -0.45 \\
\hline Birth order & -0.28 & -5.26 & -2.75 & -0.28 & -5.41 & -2.21 & -1.04 & 37.07 & -6.03 & -0.68 & 24.05 & -2.22 \\
\hline Birth month & -0.22 & -4.10 & -2.72 & -0.57 & -10.87 & -5.89 & -0.22 & 7.79 & -4.11 & -0.47 & 16.70 & -4.86 \\
\hline Mother's age at birth & 0.32 & 6.14 & 2.36 & 0.36 & 6.79 & 2.07 & 0.31 & -10.96 & 3.19 & 0.26 & -9.19 & 1.69 \\
\hline Father’s education & -0.10 & -1.97 & -1.52 & -0.24 & -4.61 & -2.90 & -1.57 & 55.88 & -7.00 & -1.63 & 58.00 & -3.89 \\
\hline Mother's education & 0.71 & 13.60 & 4.99 & 0.51 & 9.65 & 3.16 & -1.58 & 56.32 & -11.01 & -0.97 & 34.52 & -3.03 \\
\hline Rural & 0.42 & 7.99 & 1.36 & 0.79 & 15.10 & 2.65 & 0.28 & -10.11 & 2.50 & 0.46 & -16.24 & 2.63 \\
\hline Birth year & 0.58 & 11.11 & 6.06 & 0.54 & 10.33 & 4.13 & 0.73 & -26.10 & 9.51 & 0.90 & -31.90 & 7.16 \\
\hline State & 0.08 & 1.45 & 0.19 & 0.11 & 2.16 & 0.18 & 0.48 & -17.21 & 2.62 & 0.04 & -1.27 & 0.09 \\
\hline
\end{tabular}

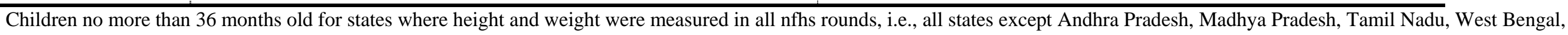
and Himachal Pradesh. See also notes to Table 7. 
Table 10: Decomposition of the Hindu-Muslim Wasting Differential

\begin{tabular}{|c|c|c|c|c|c|c|c|c|c|c|c|c|}
\hline \multirow{3}{*}{ benchmark } & \multicolumn{6}{|c|}{ Low-caste/Muslim } & \multicolumn{6}{|c|}{ High-caste/Muslim } \\
\hline & \multirow{2}{*}{$\frac{\mathrm{LC}}{\%-\text { point }}$} & \multicolumn{5}{|c|}{$\mathrm{M}$} & \multicolumn{2}{|l|}{$\mathrm{HC}$} & \multicolumn{3}{|c|}{$\mathrm{M}$} & \multirow[b]{2}{*}{ z-stat } \\
\hline & & $\begin{array}{c}\text { \% of } \\
\bar{Y}^{H}-\bar{Y}^{M}\end{array}$ & z-stat & \%-point & $\begin{array}{c}\text { \% of } \\
\bar{Y}^{H}-\bar{Y}^{M}\end{array}$ & z-stat & \%-point & $\begin{array}{c}\text { \% of } \\
\bar{Y}^{H}-\bar{Y}^{M}\end{array}$ & z-stat & \%-point & $\begin{array}{c}\text { \% of } \\
\bar{Y}^{H}-\bar{Y}^{M}\end{array}$ & \\
\hline $\bar{Y}^{H}-\bar{Y}^{M}$ & 3.43 & 100.0 & & 3.43 & 100.0 & & 0.40 & 100.0 & & 0.40 & 100.0 & \\
\hline Explained $^{\mathrm{a}}$ & 0.70 & 20.44 & & 0.31 & 8.94 & & -0.56 & -138.8 & & -0.27 & -66.67 & \\
\hline Unexplained $^{\mathrm{b}}$ & 2.73 & 79.56 & & 3.13 & 91.06 & & 0.96 & 238.8 & & 0.67 & 166.7 & \\
\hline Detailed contributions ${ }^{c}$ & & & & & & & & & & & & \\
\hline Gender & -0.01 & -0.17 & -0.39 & 0.00 & -0.10 & -0.19 & 0.01 & 2.89 & 1.24 & 0.02 & 3.82 & 0.77 \\
\hline Birth order & 0.01 & 0.27 & 0.11 & -0.07 & -2.02 & -0.66 & -0.28 & -70.20 & -2.02 & -0.11 & -27.75 & -0.46 \\
\hline Birth month & -0.19 & -5.58 & -2.70 & -0.06 & -1.88 & -0.75 & -0.03 & -7.64 & -0.70 & -0.07 & -18.43 & -0.91 \\
\hline Mother's age at birth & -0.10 & -2.84 & -0.80 & -0.06 & -1.76 & -0.42 & 0.02 & 4.56 & 0.22 & -0.07 & -16.60 & -0.48 \\
\hline Father’s education & -0.02 & -0.55 & -0.35 & -0.04 & -1.21 & -0.63 & -0.40 & -98.75 & -2.29 & -0.23 & -55.83 & -0.70 \\
\hline Mother's education & 0.19 & 5.55 & 1.48 & 0.25 & 7.37 & 1.66 & -0.39 & -96.80 & -3.36 & -0.52 & -127.7 & -2.09 \\
\hline Rural & 0.30 & 8.67 & 1.14 & 0.16 & 4.76 & 0.65 & 0.08 & 20.69 & 0.93 & 0.10 & 24.63 & 0.65 \\
\hline Birth year & -0.03 & -0.84 & -0.26 & -0.14 & -3.99 & -1.19 & 0.08 & 18.83 & 1.29 & 0.20 & 50.01 & 2.02 \\
\hline State & 0.53 & 15.55 & 1.70 & 0.26 & 7.44 & 0.55 & 0.36 & 88.20 & 2.44 & 0.41 & 102.0 & 1.38 \\
\hline
\end{tabular}

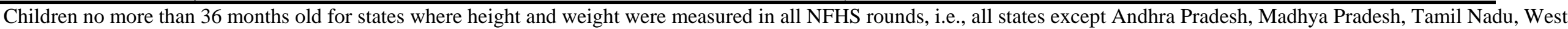

Bengal, and Himachal Pradesh. See also notes to Table 7. 
Table 11: Summary of Decomposition Results

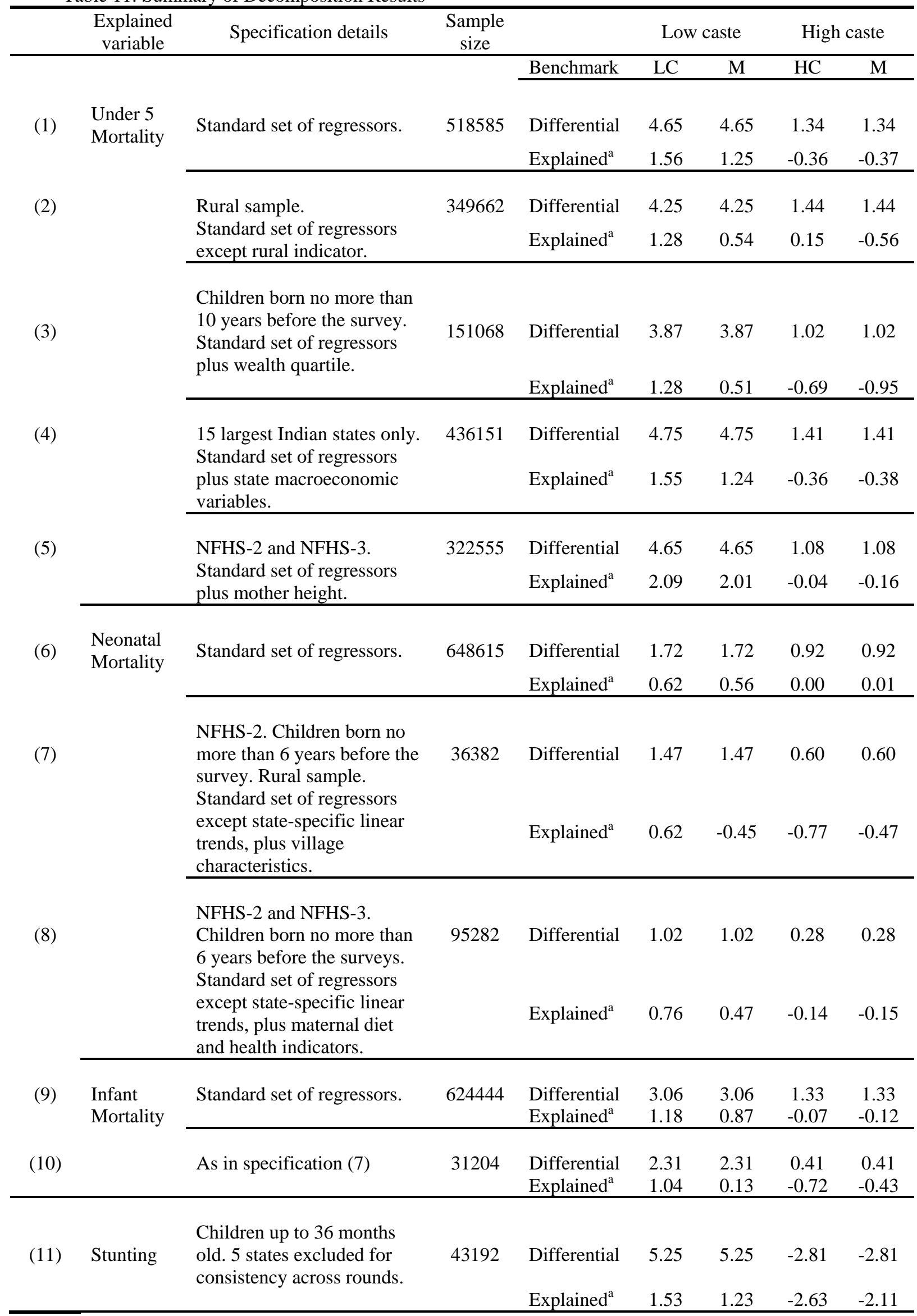




\begin{tabular}{cccccccc} 
(12) Wasting & As in specification (12) & 43354 & Differential $^{3}$ & 3.43 & 3.43 & 0.40 & 0.40 \\
& & & Explained $^{\mathrm{a}}$ & 0.70 & 0.31 & -0.56 & -0.27 \\
\hline
\end{tabular}

All samples include only children fully exposed to the relevant mortality risk. Unless specified otherwise, all samples are drawn from pooled NFHS-1, NFHS-2 and NFHS-3 data. The standard set of regressors includes indicators for gender, birth order, birth month, mother's age at birth, father's education, mother's education, rural location, year of birth of the child, state of residence, and state-specific linear time trends. The sample size reported here is the sum of all observations in community-specific logits. LC is low-caste Hindus, HC is high-caste Hindus and $\mathrm{M}$ is Muslim. ${ }^{\mathrm{a}} \sum_{i=1}^{N^{H}} \frac{F\left(X_{i}^{H} \hat{\theta}^{J}\right)}{N^{H}}-\sum_{i=1}^{N^{M}} \frac{F\left(X_{i}^{M} \hat{\theta}^{J}\right)}{N^{M}}$, where $J$ is the group used as reference. 


\section{Figures}

Figure 1

Under-5 Mortality Differential by Cohort

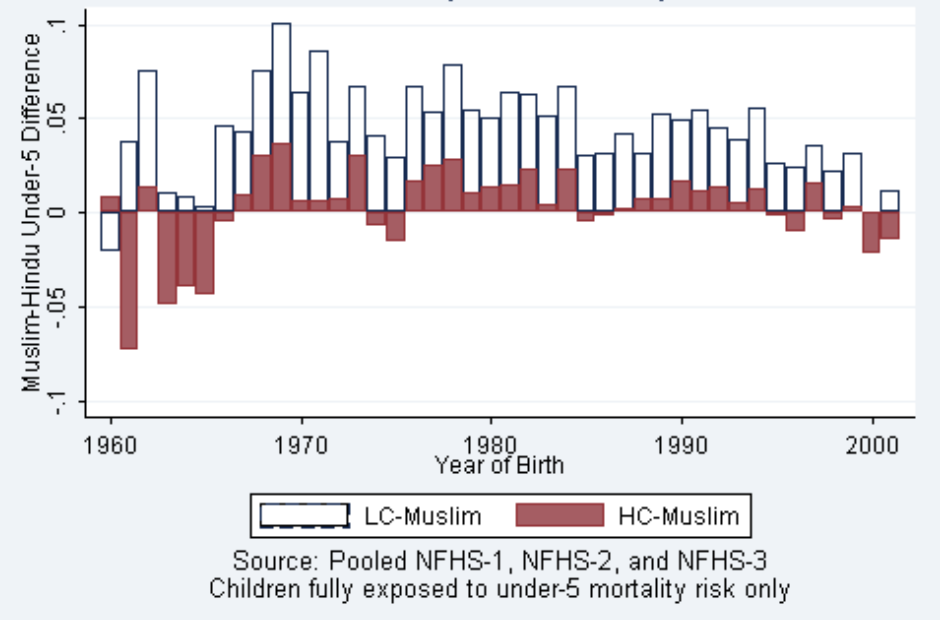

Figure 2

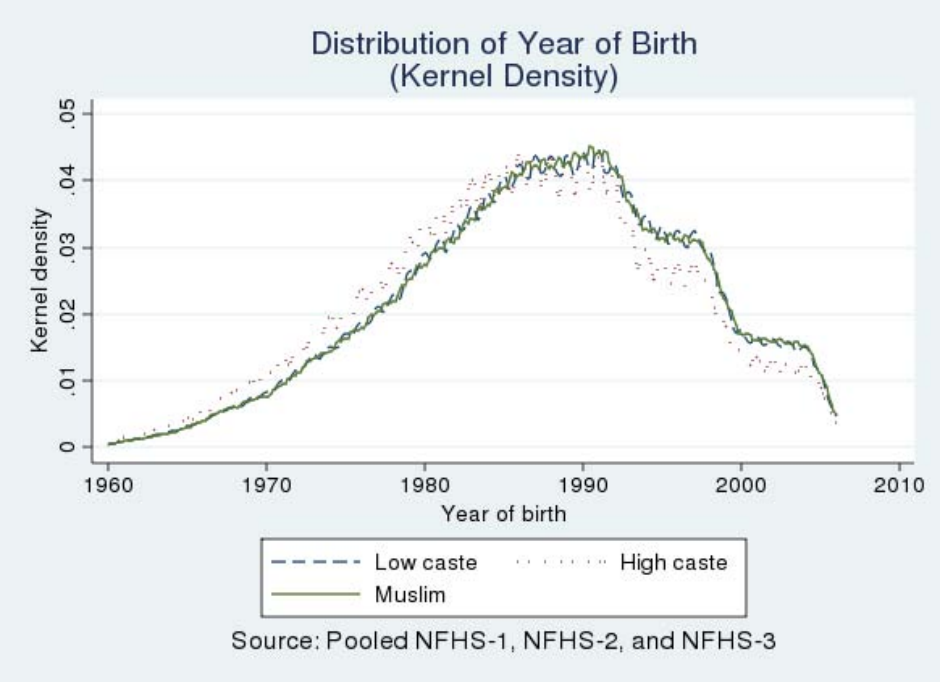




\section{Appendix}

Appendix Table 1: Summary Statistics

\begin{tabular}{|c|c|c|c|c|c|c|c|c|}
\hline & $\begin{array}{l}L C \\
(\%)\end{array}$ & $\begin{array}{c}p \text {-value of } \\
\text { Wald test } \\
\text { LC-M } M^{a}\end{array}$ & Obs. & $\begin{array}{l}H C \\
(\%)\end{array}$ & $\begin{array}{c}\text { p-value of } \\
\text { Wald test } \\
\text { HC- } M^{a}\end{array}$ & Obs. & $\begin{array}{c}M \\
(\%)\end{array}$ & Obs. \\
\hline Female & 48.13 & 0.459 & 163387 & 47.92 & 0.063 & 388634 & 48.30 & 101475 \\
\hline \multicolumn{9}{|l|}{ Child birth order: } \\
\hline First child $^{\mathrm{b}}$ & 28.00 & & 163387 & 31.30 & & 388634 & 25.60 & 101475 \\
\hline Second child & 23.92 & & 163387 & 26.26 & & 388634 & 22.01 & 101475 \\
\hline Third child & 18.32 & & 163387 & 18.06 & & 388634 & 17.18 & 101475 \\
\hline Fourth or later child & 29.76 & & 163387 & 24.38 & & 388634 & 35.21 & 101475 \\
\hline \multicolumn{9}{|l|}{ Month of birth: } \\
\hline January $^{\mathrm{b}}$ & 7.20 & 0.7473 & 163387 & 7.30 & 0.6227 & 388634 & 7.24 & 101475 \\
\hline February & 6.66 & 0.1502 & 163387 & 6.59 & 0.0280 & 388634 & 6.86 & 101475 \\
\hline March & 7.92 & 0.6911 & 163387 & 7.58 & 0.0026 & 388634 & 7.98 & 101475 \\
\hline April & 7.98 & 0.0001 & 163387 & 7.54 & & 388634 & 8.58 & 101475 \\
\hline May & 8.12 & 0.0001 & 163387 & 8.01 & & 388634 & 8.74 & 101475 \\
\hline June & 8.81 & 0.0079 & 163387 & 8.54 & & 388634 & 9.24 & 101475 \\
\hline July & 8.81 & & 163387 & 8.91 & & 388634 & 8.04 & 101475 \\
\hline August & 10.25 & & 163387 & 10.50 & & 388634 & 9.11 & 101475 \\
\hline September & 8.57 & 0.5006 & 163387 & 8.85 & 0.0048 & 388634 & 8.47 & 101475 \\
\hline October & 9.54 & & 163387 & 9.81 & & 388634 & 8.78 & 101475 \\
\hline November & 8.78 & 0.7594 & 163387 & 8.88 & 0.7290 & 388634 & 8.83 & 101475 \\
\hline December & 7.37 & & 163387 & 7.49 & & 388634 & 8.14 & 101475 \\
\hline \multicolumn{9}{|l|}{ Maternal age at birth: } \\
\hline $9-15$ & 6.19 & & 163387 & 4.52 & & 388634 & 5.13 & 101475 \\
\hline $16-18$ & 19.12 & & 163387 & 16.97 & 0.8395 & 388634 & 17.02 & 101475 \\
\hline $19-24^{b}$ & 44.34 & & 163387 & 47.39 & & 388634 & 43.13 & 101475 \\
\hline $25-30$ & 22.05 & & 163387 & 23.45 & 0.0093 & 388634 & 24.01 & 101475 \\
\hline $31-49$ & 8.30 & & 163387 & 7.66 & & 388634 & 10.71 & 101475 \\
\hline \multicolumn{9}{|l|}{ Father's education: } \\
\hline No schooling ${ }^{\mathrm{b}}$ & 50.03 & & 162354 & 28.51 & & 386677 & 43.56 & 100558 \\
\hline Primary & 21.62 & & 162354 & 22.25 & 0.0010 & 386677 & 24.08 & 100558 \\
\hline Secondary & 23.96 & & 162354 & 37.29 & & 386677 & 27.16 & 100558 \\
\hline Higher & 4.38 & 0.0031 & 162354 & 11.95 & & 386677 & 5.19 & 100558 \\
\hline \multicolumn{9}{|l|}{ Mother's education: } \\
\hline No schooling ${ }^{b}$ & 80.26 & & 163227 & 58.17 & & 388106 & 68.52 & 101265 \\
\hline Incomplete primary & 7.27 & & 163227 & 11.40 & 0.4243 & 388106 & 11.75 & 101265 \\
\hline Complete primary & 3.23 & & 163227 & 5.75 & & 388106 & 4.76 & 101265 \\
\hline Incomplete secondary & 7.73 & & 163227 & 17.96 & & 388106 & 12.19 & 101265 \\
\hline $\begin{array}{l}\text { Complete secondary and } \\
\text { higher }\end{array}$ & 1.51 & & 163227 & 6.71 & & 388106 & 2.78 & 101265 \\
\hline Rural & 83.08 & & 163387 & 74.29 & & 388634 & 64.82 & 101475 \\
\hline Urban $^{\mathrm{b}}$ & 16.92 & & 163387 & 25.71 & & 388634 & 35.18 & 101475 \\
\hline Year of birth & 1987.5 & 0.6253 & 163387 & 1986.1 & & 388634 & 1987.6 & 101475 \\
\hline \multicolumn{9}{|l|}{ State: } \\
\hline Andhra Pradesh ${ }^{\mathrm{b}}$ & 6.08 & 0.0261 & 163387 & 8.49 & & 388634 & 4.70 & 101475 \\
\hline Assam & 2.53 & & 163387 & 1.89 & & 388634 & 6.06 & 101475 \\
\hline Bihar & 9.93 & 0.0008 & 163387 & 11.94 & 0.0796 & 388634 & 14.04 & 101475 \\
\hline Goa & 0.03 & 0.0005 & 163387 & 0.11 & & 388634 & 0.06 & 101475 \\
\hline Gujarat & 5.41 & & 163387 & 5.36 & & 388634 & 3.01 & 101475 \\
\hline Haryana & 1.92 & & 163387 & 2.20 & & 388634 & 0.84 & 101475 \\
\hline Himachal Pradesh & 0.60 & & 163387 & 0.69 & & 388634 & 0.07 & 101475 \\
\hline Jammu and Kashmir & 0.45 & & 163387 & 0.38 & & 388634 & 2.69 & 101475 \\
\hline Karnataka & 4.69 & 0.6634 & 163387 & 5.48 & 0.0325 & 388634 & 4.47 & 101475 \\
\hline Kerala & 0.89 & & 163387 & 1.79 & & 388634 & 5.81 & 101475 \\
\hline Madhya Pradesh & 13.70 & & 163387 & 8.24 & & 388634 & 3.42 & 101475 \\
\hline
\end{tabular}




\begin{tabular}{|c|c|c|c|c|c|c|c|c|}
\hline Maharashtra & 6.60 & 0.1794 & 163387 & 9.21 & 0.1127 & 388634 & 7.82 & 101475 \\
\hline Manipur & 0.03 & 0.0072 & 163387 & 0.18 & 0.0934 & 388634 & 0.12 & 101475 \\
\hline Meghalaya & 0.05 & 0.6700 & 163387 & 0.02 & 0.0979 & 388634 & 0.06 & 101475 \\
\hline Mizoram & 0.004 & 0.0869 & 163387 & 0.001 & 0.6818 & 388634 & 0.002 & 101475 \\
\hline Nagaland & 0.02 & 0.1350 & 163387 & 0.01 & 0.0089 & 388634 & 0.04 & 101475 \\
\hline Orissa & 5.47 & & 163387 & 3.80 & & 388634 & 0.42 & 101475 \\
\hline Punjab & 1.53 & 0.0001 & 163387 & 0.93 & & 388634 & 0.37 & 101475 \\
\hline Rajasthan & 8.45 & & 163387 & 5.73 & 0.0008 & 388634 & 3.93 & 101475 \\
\hline Sikkim & 0.01 & & 163387 & 0.03 & & 388634 & 0.00 & 101475 \\
\hline Tamil Nadu & 5.14 & & 163387 & 6.07 & & 388634 & 2.18 & 101475 \\
\hline West Bengal & 8.01 & & 163387 & 6.08 & & 388634 & 15.47 & 101475 \\
\hline Uttar Pradesh & 17.25 & & 163387 & 19.76 & 0.0108 & 388634 & 23.31 & 101475 \\
\hline New Delhi & 0.76 & 0.4377 & 163387 & 1.28 & 0.0003 & 388634 & 0.85 & 101475 \\
\hline Arunachal Pradesh & 0.07 & & 163387 & 0.03 & 0.0002 & 388634 & 0.01 & 101475 \\
\hline Tripura & 0.39 & 0.0311 & 163387 & 0.33 & 0.1921 & 388634 & 0.25 & 101475 \\
\hline \multicolumn{9}{|c|}{ State macroeconomic variables: } \\
\hline Medical expenditure $^{c}$ & 2.843 & & 135624 & 2.772 & 0.3950 & 310877 & 2.781 & 78136 \\
\hline $\begin{array}{l}\text { Development } \\
\text { expenditure }^{c}\end{array}$ & 4.699 & & 135624 & 4.645 & 0.9949 & 310877 & 4.645 & 78136 \\
\hline Rural Gini coefficient $^{\mathrm{d}}$ & 3.273 & 0.5509 & 137294 & 3.302 & & 314073 & 3.269 & 79335 \\
\hline Urban Gini coefficient $^{\mathrm{d}}$ & 3.472 & 0.0193 & 136286 & 3.476 & 0.5529 & 312934 & 3.478 & 79348 \\
\hline $\begin{array}{l}\text { National State Domestic } \\
\text { Product }^{\mathrm{c}}\end{array}$ & 7.067 & 0.0831 & 135549 & 7.040 & 0.4095 & 310672 & 7.048 & 78024 \\
\hline
\end{tabular}

These are all the variables used in the main regressions, except that, for brevity, year dummies included in our regressions are not summarised here, and mean year of birth is presented instead. See also Figure 2. HC and LC refer to high and low caste Hindus respectively and $\mathrm{M}$ to Muslims. The sample consists of children exposed to neonatal risk across all of India's 26 states, except for state macroeconomic variables, which are averages over the 15 states for which these data are available. ${ }^{\mathrm{a}}$ If unspecified, p-value $=0.0000 .{ }^{\mathrm{b}}$ omitted category in regressions. ${ }^{\mathrm{C}}$ in real, per capita terms and in logarithm. ${ }^{\mathrm{d}}$ in logarithm. 
Appendix Table 2: Distribution of Births between States and Share Muslim in Each State

\begin{tabular}{|c|c|c|c|}
\hline & $\begin{array}{l}\text { Share of state in } \\
\text { all-India Hindu } \\
\text { population (\%) }\end{array}$ & $\begin{array}{c}\text { Share of state in } \\
\text { all-India Muslim } \\
\text { population (\%) }\end{array}$ & $\begin{array}{c}\text { Share of Muslims } \\
\text { in state } \\
\text { population (\%) }\end{array}$ \\
\hline Andhra Pradesh & 7.29 & 4.70 & 9.95 \\
\hline Assam & 2.70 & 6.06 & 34.63 \\
\hline Bihar & 11.75 & 14.04 & 18.43 \\
\hline Goa & 0.08 & 0.06 & 10.82 \\
\hline Gujarat & 5.01 & 3.01 & 9.25 \\
\hline Haryana & 1.92 & 0.84 & 6.73 \\
\hline Himachal Pradesh & 0.57 & 0.07 & 1.93 \\
\hline Jammu and Kashmir & 0.75 & 2.69 & 55.15 \\
\hline Karnataka & 5.12 & 4.47 & 13.46 \\
\hline Kerala & 2.18 & 5.81 & 41.08 \\
\hline Madhya Pradesh & 8.89 & 3.42 & 5.93 \\
\hline Maharashtra & 8.33 & 7.82 & 14.48 \\
\hline Manipur & 0.13 & 0.12 & 13.87 \\
\hline Meghalaya & 0.03 & 0.06 & 29.14 \\
\hline Mizoram & 0.00 & 0.00 & 11.65 \\
\hline Nagaland & 0.02 & 0.04 & 34.76 \\
\hline Orissa & 3.71 & 0.42 & 1.75 \\
\hline Punjab & 1.00 & 0.37 & 5.78 \\
\hline Rajasthan & 6.15 & 3.93 & 9.87 \\
\hline Sikkim & 0.02 & 0.00 & 2.73 \\
\hline Tamil Nadu & 5.23 & 2.18 & 6.41 \\
\hline West Bengal & 8.02 & 15.47 & 29.73 \\
\hline Uttar Pradesh & 19.66 & 23.31 & 18.28 \\
\hline New Delhi & 1.08 & 0.85 & 12.14 \\
\hline Arunachal Pradesh & 0.04 & 0.01 & 4.73 \\
\hline Tripura & 0.33 & 0.25 & 11.50 \\
\hline
\end{tabular}

Sample of children fully exposed to neonatal risk $(\mathrm{N}=656,411)$. 
Appendix Table 3: Under-5 Mortality Rate and Hindu-Muslim Differential by State

\begin{tabular}{|c|c|c|c|c|c|}
\hline & $\begin{array}{c}\text { Low-Caste } \\
(\%)\end{array}$ & $\begin{array}{c}L C-M \\
\text { (\%-points) }\end{array}$ & $\begin{array}{c}\text { High-caste } \\
(\%)\end{array}$ & $\begin{array}{c}H C-M \\
\text { (\%-points) }\end{array}$ & $\begin{array}{c}\text { Muslim } \\
(\%)\end{array}$ \\
\hline Andhra Pradesh & 14.04 & $7.26^{* *}$ & 11.31 & $4.53^{* *}$ & 6.78 \\
\hline Assam & 11.45 & $-2.66^{*}$ & 11.17 & $-2.94 * *$ & 14.11 \\
\hline Bihar & 16.92 & $3.70^{* *}$ & 13.48 & 0.26 & 13.22 \\
\hline Goa & 6.76 & -0.12 & 6.50 & -0.37 & 6.88 \\
\hline Gujarat & 13.42 & $4.11^{* *}$ & 10.84 & 1.52 & 9.31 \\
\hline Haryana & 12.35 & 1.08 & 9.33 & $-1.94^{+}$ & 11.27 \\
\hline Himachal Pradesh & 8.16 & 2.23 & 6.73 & 0.81 & 5.93 \\
\hline Jammu and Kashmir & 10.07 & $1.91 *$ & 7.72 & -0.44 & 8.16 \\
\hline Karnataka & 13.08 & $3.63^{* *}$ & 10.96 & $1.51 *$ & 9.46 \\
\hline Kerala & 7.69 & $2.35^{* *}$ & 4.27 & $-1.07 *$ & 5.34 \\
\hline Madhya Pradesh & 19.42 & $8.46^{* *}$ & 15.60 & $4.63 * *$ & 10.97 \\
\hline Maharashtra & 10.72 & $3.52 * *$ & 9.40 & $2.19 * *$ & 7.20 \\
\hline Manipur & 10.30 & -2.45 & 6.12 & $-6.63 * *$ & 12.75 \\
\hline Meghalaya & 9.59 & -0.19 & 7.15 & -2.64 & 9.79 \\
\hline Mizoram & 19.38 & 15.62 & 3.36 & -0.40 & 3.76 \\
\hline Nagaland & 5.54 & -4.71 & 7.50 & -2.75 & 10.25 \\
\hline Orissa & 17.31 & 2.67 & 14.28 & -0.36 & 14.64 \\
\hline Punjab & 9.52 & 1.92 & 6.67 & -0.94 & 7.60 \\
\hline Rajasthan & 15.06 & $3.24 * *$ & 12.01 & 0.19 & 11.82 \\
\hline Sikkim & 6.67 & 0.16 & 7.41 & 0.89 & 6.52 \\
\hline Tamil Nadu & 13.76 & $5.81^{* *}$ & 10.52 & $2.56 * *$ & 7.95 \\
\hline West Bengal & 13.23 & 1.14 & 10.01 & $-2.09 * *$ & 12.09 \\
\hline Uttar Pradesh & 22.05 & $7.90 * *$ & 17.59 & $3.43^{* *}$ & 14.16 \\
\hline New Delhi & 9.43 & 0.94 & 7.27 & -1.22 & 8.49 \\
\hline Arunachal Pradesh & 9.33 & -0.14 & 7.10 & -2.38 & 9.48 \\
\hline Tripura & 10.77 & $-4.24 *$ & 11.96 & $-3.05^{+}$ & 15.01 \\
\hline
\end{tabular}

${ }^{* *} \mathrm{p}<0.01,{ }^{*} \mathrm{p}<0.05,{ }^{+} \mathrm{p}<0.10$. Sample of children fully exposed to under-5 mortality risk. 


\begin{tabular}{|c|c|c|c|c|c|c|}
\hline & $\begin{array}{l}\text { Neonatal } \\
\text { mortality }\end{array}$ & & & $\begin{array}{c}\text { Infant } \\
\text { mortality }\end{array}$ & & \\
\hline & $\begin{array}{c}\text { Low-caste } \\
\text { Hindu }\end{array}$ & $\begin{array}{c}\text { High-caste } \\
\text { Hindu }\end{array}$ & Muslim & $\begin{array}{c}\text { Low-caste } \\
\text { Hindu }\end{array}$ & $\begin{array}{c}\text { High-caste } \\
\text { Hindu }\end{array}$ & Muslim \\
\hline$=1$ if child is female & $\begin{array}{c}0.811 * * \\
{[-8.76]}\end{array}$ & $\begin{array}{c}0.855^{* *} \\
{[-8.73]}\end{array}$ & $\begin{array}{c}0.809 * * \\
{[-5.77]}\end{array}$ & $\begin{array}{c}0.939 * * \\
{[-3.14]}\end{array}$ & $\begin{array}{c}0.972 \\
{[-1.94]}\end{array}$ & $\begin{array}{l}0.935 * \\
{[-2.18]}\end{array}$ \\
\hline
\end{tabular}

Child birth order (omitted: first child)

$\begin{array}{lcccccc}\text { Second child } & 0.860^{* *} & 0.827^{* *} & 0.782^{* *} & 0.984 & 0.934^{* *} & 0.922 \\ & {[-4.51]} & {[-7.99]} & {[-4.53]} & {[-0.57]} & {[-3.40]} & {[-1.87]} \\ \text { Third child } & 0.835^{* *} & 0.845^{* *} & 0.793^{* *} & 0.986 & 0.999 & 0.956 \\ & {[-4.19]} & {[-5.63]} & {[-3.59]} & {[-0.39]} & {[-0.058]} & {[-0.84]} \\ \text { Fourth or later child } & 1.083 & 1.091^{*} & 0.933 & 1.309 * * & 1.340^{* *} & 1.207 * * \\ & {[1.66]} & {[2.54]} & {[-0.93]} & {[6.76]} & {[10.3]} & {[3.12]}\end{array}$

Month of birth (omitted: January)

\begin{tabular}{|c|c|c|c|c|c|c|}
\hline February & $\begin{array}{c}0.913 \\
{[-1.49]}\end{array}$ & $\begin{array}{c}1.003 \\
{[0.074]}\end{array}$ & $\begin{array}{c}0.989 \\
{[-0.12]}\end{array}$ & $\begin{array}{c}0.999 \\
{[-0.012]}\end{array}$ & $\begin{array}{c}1.018 \\
{[0.48]}\end{array}$ & $\begin{array}{c}1.042 \\
{[0.54]}\end{array}$ \\
\hline March & $\begin{array}{l}0.862 * \\
{[-2.47]}\end{array}$ & $\begin{array}{l}0.907 * \\
{[-2.16]}\end{array}$ & $\begin{array}{c}0.844 \\
{[-1.83]}\end{array}$ & $\begin{array}{c}0.907 \\
{[-1.94]}\end{array}$ & $\begin{array}{c}0.936 \\
{[-1.77]}\end{array}$ & $\begin{array}{c}0.964 \\
{[-0.48]}\end{array}$ \\
\hline April & $\begin{array}{c}0.919 \\
{[-1.36]}\end{array}$ & $\begin{array}{c}1.003 \\
{[0.065]}\end{array}$ & $\begin{array}{c}0.87 \\
{[-1.48]}\end{array}$ & $\begin{array}{c}0.995 \\
{[-0.090]}\end{array}$ & $\begin{array}{c}1.034 \\
{[0.91]}\end{array}$ & $\begin{array}{c}0.903 \\
{[-1.27]}\end{array}$ \\
\hline May & $\begin{array}{c}1.003 \\
{[0.058]}\end{array}$ & $\begin{array}{c}1.046 \\
{[1.03]}\end{array}$ & $\begin{array}{c}1.081 \\
{[0.91]}\end{array}$ & $\begin{array}{c}1.028 \\
{[0.55]}\end{array}$ & $\begin{array}{c}1.071 \\
{[1.89]}\end{array}$ & $\begin{array}{l}1.119 \\
{[1.62]}\end{array}$ \\
\hline June & $\begin{array}{c}0.986 \\
{[-0.23]}\end{array}$ & $\begin{array}{c}0.989 \\
{[-0.27]}\end{array}$ & $\begin{array}{c}1.04 \\
{[0.43]}\end{array}$ & $\begin{array}{c}1.032 \\
{[0.61]}\end{array}$ & $\begin{array}{l}1.033 \\
{[0.92]}\end{array}$ & $\begin{array}{c}1.115 \\
{[1.41]}\end{array}$ \\
\hline July & $\begin{array}{c}0.948 \\
{[-0.93]}\end{array}$ & $\begin{array}{c}1.021 \\
{[0.48]}\end{array}$ & $\begin{array}{c}0.999 \\
{[-0.012]}\end{array}$ & $\begin{array}{l}1.014 \\
{[0.27]}\end{array}$ & $\begin{array}{c}1.027 \\
{[0.75]}\end{array}$ & $\begin{array}{c}1.044 \\
{[0.55]}\end{array}$ \\
\hline August & $\begin{array}{c}1.067 \\
{[1.10]}\end{array}$ & $\begin{array}{l}1.064 \\
{[1.53]}\end{array}$ & $\begin{array}{c}1.139 \\
{[1.53]}\end{array}$ & $\begin{array}{l}1.062 \\
{[1.24]}\end{array}$ & $\begin{array}{c}1.052 \\
{[1.51]}\end{array}$ & $\begin{array}{l}1.155 \\
{[1.93]}\end{array}$ \\
\hline September & $\begin{array}{c}0.999 \\
{[-0.015]}\end{array}$ & $\begin{array}{l}1.008 \\
{[0.17]}\end{array}$ & $\begin{array}{c}1.012 \\
{[0.14]}\end{array}$ & $\begin{array}{c}1.036 \\
{[0.73]}\end{array}$ & $\begin{array}{l}1.022 \\
{[0.62]}\end{array}$ & $\begin{array}{c}1.073 \\
{[0.95]}\end{array}$ \\
\hline October & $\begin{array}{c}0.839 * * \\
{[-3.07]}\end{array}$ & $\begin{array}{c}0.95 \\
{[-1.21]}\end{array}$ & $\begin{array}{c}0.906 \\
{[-1.05]}\end{array}$ & $\begin{array}{c}0.918 \\
{[-1.81]}\end{array}$ & $\begin{array}{c}0.948 \\
{[-1.49]}\end{array}$ & $\begin{array}{c}0.949 \\
{[-0.69]}\end{array}$ \\
\hline November & $\begin{array}{c}0.919 \\
{[-1.42]}\end{array}$ & $\begin{array}{c}0.968 \\
{[-0.77]}\end{array}$ & $\begin{array}{c}0.903 \\
{[-1.10]}\end{array}$ & $\begin{array}{c}0.93 \\
{[-1.42]}\end{array}$ & $\begin{array}{c}0.987 \\
{[-0.37]}\end{array}$ & $\begin{array}{c}0.873 \\
{[-1.73]}\end{array}$ \\
\hline December & $\begin{array}{c}0.951 \\
{[-0.83]}\end{array}$ & $\begin{array}{c}1.057 \\
{[1.25]}\end{array}$ & $\begin{array}{c}1.006 \\
{[0.070]}\end{array}$ & $\begin{array}{c}1.031 \\
{[0.59]}\end{array}$ & $\begin{array}{c}1.024 \\
{[0.63]}\end{array}$ & $\begin{array}{c}1.07 \\
{[0.90]}\end{array}$ \\
\hline
\end{tabular}

Maternal age at birth (omitted: age 19-24)

\begin{tabular}{|c|c|c|c|c|c|c|}
\hline Age 9-15 & $\begin{array}{c}2.066^{* *} \\
{[14.3]}\end{array}$ & $\begin{array}{c}1.901 * * \\
{[16.7]}\end{array}$ & $\begin{array}{c}1.720 * * \\
{[6.83]}\end{array}$ & $\begin{array}{c}1.967 * * \\
{[15.4]}\end{array}$ & $\begin{array}{c}1.904^{* *} \\
{[19.6]}\end{array}$ & $\begin{array}{c}1.863 * * \\
{[9.56]}\end{array}$ \\
\hline Age 16-18 & $\begin{array}{c}1.435^{* *} \\
{[10.0]}\end{array}$ & $\begin{array}{c}1.449 * * \\
{[14.5]}\end{array}$ & $\begin{array}{c}1.363 * * \\
{[5.54]}\end{array}$ & $\begin{array}{c}1.443 * * \\
{[12.3]}\end{array}$ & $\begin{array}{c}1.431 * * \\
{[17.0]}\end{array}$ & $\begin{array}{c}1.426 * * \\
{[7.65]}\end{array}$ \\
\hline Age 25-30 & $\begin{array}{c}0.793 * * \\
{[-5.62]}\end{array}$ & $\begin{array}{c}0.772 * * \\
{[-9.49]}\end{array}$ & $\begin{array}{c}0.904 \\
{[-1.66]}\end{array}$ & $\begin{array}{c}0.776 * * \\
{[-7.69]}\end{array}$ & $\begin{array}{c}0.755 * * \\
{[-12.6]}\end{array}$ & $\begin{array}{c}0.846 * * \\
{[-3.41]}\end{array}$ \\
\hline Age 31-49 & $\begin{array}{c}0.786 * * \\
{[-3.88]}\end{array}$ & $\begin{array}{c}0.826 * * \\
{[-4.60]}\end{array}$ & $\begin{array}{c}0.876 \\
{[-1.63]}\end{array}$ & $\begin{array}{c}0.759 * * \\
{[-5.68]}\end{array}$ & $\begin{array}{c}0.787 * * \\
{[-6.96]}\end{array}$ & $\begin{array}{l}0.852 * \\
{[-2.51]}\end{array}$ \\
\hline
\end{tabular}

Father's education (omitted: no schooling)

\begin{tabular}{lcccccc} 
Primary & 0.969 & 0.953 & 0.927 & 0.957 & $0.937^{* *}$ & $0.889^{* *}$ \\
& {$[-0.88]$} & {$[-1.82]$} & {$[-1.43]$} & {$[-1.51]$} & {$[-2.99]$} & {$[-2.71]$} \\
Secondary & $0.910^{*}$ & $0.876^{* *}$ & $0.877^{*}$ & $0.853^{* *}$ & $0.811^{* *}$ & $0.818^{* *}$ \\
\hline
\end{tabular}




\begin{tabular}{lcccccc}
\hline & {$[-2.41]$} & {$[-4.88]$} & {$[-2.36]$} & {$[-4.85]$} & {$[-9.33]$} & {$[-4.42]$} \\
Higher & 0.901 & $0.721^{* *}$ & 0.867 & $0.785^{* *}$ & $0.661^{* *}$ & $0.809^{*}$ \\
& {$[-1.20]$} & {$[-7.52]$} & {$[-1.13]$} & {$[-3.37]$} & {$[-11.3]$} & {$[-1.98]$}
\end{tabular}

Mother's education (omitted: no schooling)

\begin{tabular}{|c|c|c|c|c|c|c|}
\hline Incomplete primary & $\begin{array}{c}0.911 \\
{[-1.63]}\end{array}$ & $\begin{array}{r}0.882^{* *} \\
{[-4.01]}\end{array}$ & $\begin{array}{c}0.867 \\
{[-1.87]}\end{array}$ & $\begin{array}{l}0.898^{*} \\
{[-2.16]}\end{array}$ & $\begin{array}{c}0.860 * * \\
{[-5.79]}\end{array}$ & $\begin{array}{c}0.817^{* *} \\
{[-3.12]}\end{array}$ \\
\hline \multirow[t]{2}{*}{ Complete primary } & 0.9 & $0.836^{* *}$ & 0.861 & $0.812^{*}$ & $0.822^{* *}$ & $0.811^{*}$ \\
\hline & {$[-1.15]$} & {$[-3.95]$} & {$[-1.33]$} & {$[-2.56]$} & {$[-5.15]$} & {$[-2.25]$} \\
\hline \multirow{2}{*}{$\begin{array}{l}\text { Incomplete } \\
\text { secondary }\end{array}$} & $0.773^{* *}$ & $0.755^{* *}$ & $0.804^{*}$ & $0.742^{* *}$ & $0.712^{* *}$ & $0.773 * *$ \\
\hline & {$[-3.88]$} & {$[-8.17]$} & {$[-2.56]$} & {$[-5.36]$} & {$[-11.6]$} & {$[-3.66]$} \\
\hline \multirow{2}{*}{$\begin{array}{l}\text { Complete secondary } \\
\text { and higher }\end{array}$} & $0.701^{*}$ & $0.665^{* *}$ & $0.601^{* *}$ & $0.612^{* *}$ & $0.616^{* *}$ & $0.590 * *$ \\
\hline & {$[-2.49]$} & {$[-7.12]$} & {$[-2.67]$} & {$[-3.71]$} & {$[-9.71]$} & {$[-2.97]$} \\
\hline$=1$ if rural & $\begin{array}{c}1.241^{* *} \\
{[4.66]}\end{array}$ & $\begin{array}{c}1.189 * * \\
{[6.34]}\end{array}$ & $\begin{array}{c}1.296^{* *} \\
{[4.96]}\end{array}$ & $\begin{array}{c}1.239 * * \\
{[5.60]}\end{array}$ & $\begin{array}{c}1.177^{* *} \\
{[7.08]}\end{array}$ & $\begin{array}{c}1.235 * * \\
{[4.79]}\end{array}$ \\
\hline Constant & $\begin{array}{c}0.025^{* *} \\
{[-8.86]}\end{array}$ & $\begin{array}{c}0.122^{* *} \\
{[-9.44]}\end{array}$ & $\begin{array}{c}0.072 * * \\
{[-4.26]}\end{array}$ & $\begin{array}{c}0.066 * * \\
{[-8.97]}\end{array}$ & $\begin{array}{c}0.160 * * \\
{[-9.13]}\end{array}$ & $\begin{array}{r}0.105^{* *} \\
{[-4.36]}\end{array}$ \\
\hline Observations & 162201 & 386081 & 100333 & 155871 & 372348 & 96225 \\
\hline Pseudo $\mathrm{R}^{2}$ & 0.031 & 0.033 & 0.034 & 0.037 & 0.043 & 0.039 \\
\hline \multicolumn{7}{|c|}{ P-value of joint significance test: } \\
\hline State dummies & 0.0000 & 0.0000 & 0.2581 & 0.0000 & 0.0000 & 0.0271 \\
\hline State trends & 0.0000 & 0.0002 & 0.3611 & 0.0000 & 0.0000 & 0.0856 \\
\hline Year dummies & 0.0002 & 0.0000 & 0.0001 & 0.0000 & 0.0000 & 0.0000 \\
\hline
\end{tabular}

Year dummies, state dummies and state-specific linear trends omitted for brevity. Full results available on request. Robust z statistics in brackets. ${ }^{* *} \mathrm{p}<0.01,{ }^{*} \mathrm{p}<0.05$. 


\begin{tabular}{|c|c|c|c|c|c|c|}
\hline & \multicolumn{3}{|c|}{ Rural + Urban } & \multicolumn{3}{|c|}{ Rural only } \\
\hline & $\begin{array}{c}\text { Low-caste } \\
\text { Hindu }\end{array}$ & $\begin{array}{c}\text { High-caste } \\
\text { Hindu }\end{array}$ & Muslim & $\begin{array}{c}\text { Low-caste } \\
\text { Hindu }\end{array}$ & $\begin{array}{c}\text { High-caste } \\
\text { Hindu }\end{array}$ & Muslim \\
\hline$=1$ if child is female & $\begin{array}{c}1.003 \\
{[0.18]}\end{array}$ & $\begin{array}{c}1.059 * * \\
{[4.07]}\end{array}$ & $\begin{array}{c}1.004 \\
{[0.16]}\end{array}$ & $\begin{array}{l}1.007 \\
{[0.35]}\end{array}$ & $\begin{array}{c}1.081 * * \\
{[5.03]}\end{array}$ & $\begin{array}{l}1.025 \\
{[0.75]}\end{array}$ \\
\hline
\end{tabular}

Child birth order (omitted: first child)

\begin{tabular}{|c|c|c|c|c|c|c|}
\hline Second child & $\begin{array}{c}1.115^{* *} \\
{[4.14]}\end{array}$ & $\begin{array}{l}1.044 * \\
{[2.19]}\end{array}$ & $\begin{array}{c}1.115^{* *} \\
{[2.60]}\end{array}$ & $\begin{array}{c}1.144^{* *} \\
{[4.68]}\end{array}$ & $\begin{array}{c}1.046 \\
{[1.96]}\end{array}$ & $\begin{array}{c}1.08 \\
{[1.50]}\end{array}$ \\
\hline Third child & $\begin{array}{c}1.200 * * \\
{[5.45]}\end{array}$ & $\begin{array}{c}1.147^{* *} \\
{[5.69]}\end{array}$ & $\begin{array}{l}1.145 * \\
{[2.49]}\end{array}$ & $\begin{array}{c}1.224^{* *} \\
{[5.60]}\end{array}$ & $\begin{array}{c}1.171^{* *} \\
{[5.76]}\end{array}$ & $\begin{array}{c}1.115 \\
{[1.61]}\end{array}$ \\
\hline Fourth or later child & $\begin{array}{c}1.550 * * \\
{[11.9]}\end{array}$ & $\begin{array}{c}1.516^{* *} \\
{[15.4]}\end{array}$ & $\begin{array}{c}1.426^{* *} \\
{[6.06]}\end{array}$ & $\begin{array}{c}1.586 * * \\
{[11.5]}\end{array}$ & $\begin{array}{c}1.541^{* *} \\
{[14.0]}\end{array}$ & $\begin{array}{c}1.367 * * \\
{[4.33]}\end{array}$ \\
\hline
\end{tabular}

Month of birth (omitted: January)

\begin{tabular}{|c|c|c|c|c|c|c|}
\hline February & $\begin{array}{c}0.944 \\
{[-1.11]}\end{array}$ & $\begin{array}{l}1.045 \\
{[1.27]}\end{array}$ & $\begin{array}{c}1.066 \\
{[0.87]}\end{array}$ & $\begin{array}{c}0.94 \\
{[-1.10]}\end{array}$ & $\begin{array}{c}1.017 \\
{[0.43]}\end{array}$ & $\begin{array}{c}1.062 \\
{[0.67]}\end{array}$ \\
\hline \multirow[t]{2}{*}{ March } & $0.900 *$ & 0.945 & 1.015 & 0.918 & 0.934 & 0.997 \\
\hline & {$[-2.16]$} & {$[-1.62]$} & {$[0.21]$} & {$[-1.61]$} & {$[-1.72]$} & {$[-0.034]$} \\
\hline \multirow[t]{2}{*}{ April } & 0.978 & 1.027 & 0.948 & 0.989 & 1.003 & 0.982 \\
\hline & {$[-0.44]$} & {$[0.80]$} & {$[-0.72]$} & {$[-0.20]$} & [0.092] & {$[-0.20]$} \\
\hline \multirow[t]{2}{*}{ May } & 0.993 & 1.048 & 1.033 & 1.004 & 1.032 & 1.026 \\
\hline & {$[-0.15]$} & [1.36] & {$[0.47]$} & [0.072] & {$[0.80]$} & [0.31] \\
\hline \multirow[t]{2}{*}{ June } & 0.993 & 1.021 & 1.077 & 1.018 & 1.007 & 1.106 \\
\hline & {$[-0.15]$} & {$[0.62]$} & [1.05] & [0.33] & [0.19] & [1.21] \\
\hline \multirow[t]{2}{*}{ July } & 0.978 & 1.005 & 1.034 & 0.976 & 0.995 & 1.01 \\
\hline & {$[-0.48]$} & {$[0.16]$} & {$[0.47]$} & [-0.49] & {$[-0.14]$} & [0.12] \\
\hline \multirow[t]{2}{*}{ August } & 1.039 & 1.034 & 1.118 & 1.082 & 1.024 & 1.158 \\
\hline & {$[0.83]$} & [1.03] & [1.57] & [1.59] & {$[0.65]$} & [1.70] \\
\hline \multirow[t]{2}{*}{ September } & 1.022 & 1.006 & 1.03 & 1.036 & 1.008 & 1.052 \\
\hline & {$[0.47]$} & [0.18] & [0.43] & {$[0.71]$} & {$[0.22]$} & [0.62] \\
\hline \multirow[t]{2}{*}{ October } & 0.916 & 0.967 & 0.94 & 0.939 & 0.964 & 1.011 \\
\hline & [-1.92] & {$[-1.01]$} & {$[-0.85]$} & {$[-1.29]$} & [-0.97] & {$[0.12]$} \\
\hline \multirow[t]{2}{*}{ November } & 0.927 & 0.957 & $0.810 * *$ & 0.961 & 0.962 & $0.814^{*}$ \\
\hline & [-1.59] & {$[-1.26]$} & [-2.77] & {$[-0.77]$} & [-0.99] & [-2.24] \\
\hline \multirow[t]{2}{*}{ December } & 0.996 & 1.001 & 0.981 & 1.005 & 1.013 & 0.951 \\
\hline & {$[-0.088]$} & [0.029] & {$[-0.24]$} & [0.086] & [0.33] & {$[-0.55]$} \\
\hline
\end{tabular}

Maternal age at birth (omitted: age 19-24)

\begin{tabular}{|c|c|c|c|c|c|c|}
\hline Age 9-15 & $\begin{array}{c}1.930 * * \\
{[15.8]}\end{array}$ & $\begin{array}{c}1.880 * * \\
{[20.1]}\end{array}$ & $\begin{array}{c}2.020 * * \\
{[10.4]}\end{array}$ & $\begin{array}{c}1.951 * * \\
{[14.6]}\end{array}$ & $\begin{array}{c}1.879 * * \\
{[18.0]}\end{array}$ & $\begin{array}{c}1.966 * * \\
{[8.21]}\end{array}$ \\
\hline Age 16-18 & $\begin{array}{c}1.442 * * \\
{[13.0]}\end{array}$ & $\begin{array}{c}1.418 * * \\
{[17.0]}\end{array}$ & $\begin{array}{c}1.397 * * \\
{[7.62]}\end{array}$ & $\begin{array}{c}1.454^{* *} \\
{[12.3]}\end{array}$ & $\begin{array}{c}1.413^{* *} \\
{[15.0]}\end{array}$ & $\begin{array}{c}1.395 * * \\
{[6.17]}\end{array}$ \\
\hline Age 25-30 & $\begin{array}{c}0.761 * * \\
{[-8.66]}\end{array}$ & $\begin{array}{c}0.748 * * \\
{[-13.5]}\end{array}$ & $\begin{array}{c}0.862 * * \\
{[-3.31]}\end{array}$ & $\begin{array}{c}0.761 * * \\
{[-8.00]}\end{array}$ & $\begin{array}{c}0.738 * * \\
{[-12.3]}\end{array}$ & $\begin{array}{l}0.877^{*} \\
{[-2.43]}\end{array}$ \\
\hline Age 31-49 & $\begin{array}{c}0.736 * * \\
{[-6.45]}\end{array}$ & $\begin{array}{c}0.762 * * \\
{[-7.87]}\end{array}$ & $\begin{array}{c}0.795 * * \\
{[-3.63]}\end{array}$ & $\begin{array}{c}0.728 * * \\
{[-6.18]}\end{array}$ & $\begin{array}{c}0.759 * * \\
{[-7.16]}\end{array}$ & $\begin{array}{c}0.767 * * \\
{[-3.46]}\end{array}$ \\
\hline
\end{tabular}

Father’s education (omitted: no schooling)

\begin{tabular}{lccccccc} 
Primary & $0.925 * *$ & $0.882^{* *}$ & $0.864^{* *}$ & $0.935^{*}$ & $0.879 * *$ & $0.871^{* *}$ \\
Secondary & {$[-2.79]$} & {$[-6.05]$} & {$[-3.58]$} & {$[-2.21]$} & {$[-5.75]$} & {$[-2.88]$} \\
& $0.788^{* *}$ & $0.741^{* *}$ & $0.788^{* *}$ & $0.793^{* *}$ & $0.750^{* *}$ & $0.759^{* *}$ \\
\hline
\end{tabular}




\begin{tabular}{lcccccc}
\hline Higher & $0.690^{* *}$ & $0.588^{* *}$ & $0.729^{* *}$ & $0.755^{* *}$ & $0.603^{* *}$ & $0.633^{* *}$ \\
& {$[-5.23]$} & {$[-14.7]$} & {$[-3.18]$} & {$[-3.58]$} & {$[-11.6]$} & {$[-3.39]$}
\end{tabular}

Mother's education (omitted: no schooling)

\begin{tabular}{|c|c|c|c|c|c|c|}
\hline Incomplete primary & $\begin{array}{c}0.865 * * \\
{[-3.00]}\end{array}$ & $\begin{array}{c}0.831 * * \\
{[-7.45]}\end{array}$ & $\begin{array}{c}0.742 * * \\
{[-4.89]}\end{array}$ & $\begin{array}{c}0.853 * * \\
{[-2.85]}\end{array}$ & $\begin{array}{c}0.859 * * \\
{[-5.35]}\end{array}$ & $\begin{array}{c}0.744 * * \\
{[-4.01]}\end{array}$ \\
\hline \multirow[t]{2}{*}{ Complete primary } & $0.784 * *$ & $0.801 * *$ & $0.750 * *$ & $0.726 * *$ & $0.803 * *$ & $0.665 * *$ \\
\hline & {$[-3.19]$} & {$[-6.13]$} & {$[-3.01]$} & {$[-3.65]$} & {$[-5.11]$} & {$[-2.95]$} \\
\hline \multirow{2}{*}{$\begin{array}{l}\text { Incomplete } \\
\text { secondary }\end{array}$} & $0.713^{* *}$ & $0.665 * *$ & $0.715^{* *}$ & $0.715^{* *}$ & $0.714^{* *}$ & $0.760 * *$ \\
\hline & {$[-5.83]$} & {$[-14.2]$} & {$[-4.75]$} & {$[-4.63]$} & {$[-9.47]$} & {$[-2.78]$} \\
\hline \multirow{2}{*}{$\begin{array}{l}\text { Complete secondary } \\
\text { and higher }\end{array}$} & $0.533^{* *}$ & $0.586 * *$ & $0.558 * *$ & $0.649 *$ & $0.635^{* *}$ & 0.674 \\
\hline & [-4.39] & {$[-10.5]$} & {$[-3.18]$} & {$[-2.33]$} & {$[-5.33]$} & {$[-1.10]$} \\
\hline$=1$ if rural & $\begin{array}{c}1.272^{* *} \\
{[6.98]}\end{array}$ & $\begin{array}{c}1.206 * * \\
{[8.17]}\end{array}$ & $\begin{array}{c}1.273^{* *} \\
{[5.68]}\end{array}$ & & & \\
\hline \multirow[t]{2}{*}{ Constant } & $0.128 * *$ & $0.210 * *$ & $0.157 * *$ & $0.154 * *$ & $0.255^{* *}$ & $0.165^{* *}$ \\
\hline & {$[-7.27]$} & {$[-8.52]$} & {$[-4.01]$} & {$[-6.13]$} & {$[-6.53]$} & {$[-2.94]$} \\
\hline Observations & 128297 & 311863 & 78425 & 98938 & 206388 & 44336 \\
\hline Pseudo $\mathrm{R}^{2}$ & 0.043 & 0.051 & 0.044 & 0.039 & 0.043 & 0.039 \\
\hline \multicolumn{7}{|c|}{ P-value of joint significance test: } \\
\hline State dummies & 0.0000 & 0.0000 & 0.0007 & 0.0000 & 0.0000 & 0.0238 \\
\hline State trends & 0.0000 & 0.0004 & 0.0000 & 0.0000 & 0.0001 & 0.0278 \\
\hline Year dummies & 0.0000 & 0.0000 & 0.0001 & 0.0000 & 0.0000 & 0.0006 \\
\hline
\end{tabular}

Year dummies, state dummies and state-specific linear trends omitted for brevity. Full results available on request. Robust $\mathrm{z}$ statistics in brackets. ${ }^{* *} \mathrm{p}<0.01,{ }^{*} \mathrm{p}<0.05$. 
Appendix Table 6: Decomposition of the Hindu-Muslim Neonatal Mortality Differential

\begin{tabular}{|c|c|c|c|c|c|c|c|c|c|c|c|c|}
\hline \multirow{3}{*}{ Benchmark } & \multicolumn{6}{|c|}{ Low-caste/Muslim } & \multicolumn{6}{|c|}{ High-caste/Muslim } \\
\hline & LC & & & $\mathrm{M}$ & & & $\mathrm{HC}$ & & & $\mathrm{M}$ & & \\
\hline & \%-point & $\begin{array}{c}\text { \% of } \\
\bar{Y}^{H}-\bar{Y}^{M}\end{array}$ & z-stat & \%-point & $\begin{array}{c}\text { \% of } \\
\bar{Y}^{H}-\bar{Y}^{M}\end{array}$ & z-stat & \%-point & $\begin{array}{c}\text { \% of } \\
\bar{Y}^{H}-\bar{Y}^{M}\end{array}$ & z-stat & \%-point & $\begin{array}{c}\text { \% of } \\
\bar{Y}^{H}-\bar{Y}^{M}\end{array}$ & z-stat \\
\hline $\bar{Y}^{H}-\bar{Y}^{M}$ & 1.72 & 100.00 & & 1.72 & 100.00 & & 0.92 & 100.00 & & 0.92 & 100.00 & \\
\hline Explained $^{\mathrm{a}}$ & 0.62 & 36.13 & & 0.56 & 32.46 & & 0.00 & 0.38 & & 0.01 & 1.53 & \\
\hline Unexplained $^{\mathrm{b}}$ & 1.10 & 63.87 & & 1.16 & 67.54 & & 0.92 & 99.62 & & 0.91 & 98.47 & \\
\hline $\begin{array}{l}\text { Detailed } \\
\text { contributions }\end{array}$ & & & & & & & & & & & & \\
\hline Gender & 0.00 & 0.24 & 0.63 & 0.00 & 0.26 & 0.52 & 0.00 & -0.31 & -1.05 & 0.00 & -0.40 & -0.46 \\
\hline Birth order & -0.05 & -2.80 & -2.20 & -0.01 & -0.65 & -0.50 & -0.08 & -9.08 & -4.54 & -0.02 & -1.93 & -0.60 \\
\hline Birth month & 0.00 & 0.01 & 0.03 & 0.00 & 0.27 & 0.52 & 0.00 & 0.02 & 0.04 & 0.01 & 0.97 & 0.90 \\
\hline Mother's age at birth & 0.18 & 10.62 & 4.10 & 0.09 & 5.47 & 2.69 & 0.02 & 2.16 & 0.76 & 0.00 & -0.29 & -0.08 \\
\hline Father’s education & 0.02 & 1.25 & 2.03 & 0.03 & 1.53 & 2.13 & -0.17 & -18.02 & -6.50 & -0.11 & -11.57 & -2.28 \\
\hline Mother's education & 0.10 & 5.88 & 3.69 & 0.09 & 5.03 & 3.15 & -0.14 & -15.38 & -8.61 & -0.12 & -13.54 & -3.39 \\
\hline Rural & 0.23 & 13.50 & 4.85 & 0.21 & 12.04 & 4.70 & 0.11 & 12.14 & 6.38 & 0.12 & 12.80 & 4.27 \\
\hline Birth year & 0.00 & 0.10 & 0.07 & 0.03 & 1.53 & 0.47 & 0.16 & 17.05 & 3.04 & 0.12 & 12.75 & 1.04 \\
\hline State & -0.22 & -12.84 & -0.68 & -0.19 & -11.23 & -0.50 & 0.07 & 7.52 & 0.50 & -0.24 & -26.47 & -0.75 \\
\hline State trends & 0.35 & 20.07 & 1.12 & 0.31 & 18.13 & 0.81 & 0.04 & 4.18 & 0.25 & 0.27 & 29.11 & 0.77 \\
\hline
\end{tabular}


Appendix Table 7: Decomposition of the Hindu-Muslim Infant Mortality Differential

\begin{tabular}{|c|c|c|c|c|c|c|c|c|c|c|c|c|}
\hline \multirow{3}{*}{ Benchmark } & \multicolumn{6}{|c|}{ Low-caste/Muslim } & \multicolumn{6}{|c|}{ High-caste/Muslim } \\
\hline & $\mathrm{LC}$ & & & $\mathrm{M}$ & & & $\mathrm{HC}$ & & & $\mathrm{M}$ & & \\
\hline & \%-point & $\begin{array}{c}\text { \% of } \\
\bar{Y}^{H}-\bar{Y}^{M}\end{array}$ & z-stat & \%-point & $\begin{array}{c}\text { \% of } \\
\bar{Y}^{H}-\bar{Y}^{M}\end{array}$ & z-stat & \%-point & $\begin{array}{c}\text { \% of } \\
\bar{Y}^{H}-\bar{Y}^{M}\end{array}$ & z-stat & \%-point & $\begin{array}{c}\text { \% of } \\
\bar{Y}^{H}-\bar{Y}^{M}\end{array}$ & z-stat \\
\hline $\bar{Y}^{H}-\bar{Y}^{M}$ & 3.06 & 100.00 & & 3.06 & 100.00 & & 1.33 & 100.00 & & 1.33 & 100.00 & \\
\hline Explained $^{\mathrm{a}}$ & 1.18 & 38.37 & & 0.87 & 28.30 & & -0.07 & -5.33 & & -0.12 & -8.88 & \\
\hline Unexplained $^{\mathrm{b}}$ & 1.89 & 61.63 & & 2.20 & 71.70 & & 1.40 & 105.33 & & 1.45 & 108.88 & \\
\hline $\begin{array}{l}\text { Detailed } \\
\text { contributions }\end{array}$ & & & & & & & & & & & & \\
\hline Gender & 0.00 & 0.01 & 0.14 & 0.00 & 0.02 & 0.23 & 0.00 & 0.05 & 0.98 & 0.00 & 0.05 & 0.28 \\
\hline Birth order & -0.13 & -4.38 & -4.34 & -0.09 & -2.98 & -2.58 & -0.24 & -17.73 & -9.03 & -0.14 & -10.77 & -3.42 \\
\hline Birth month & 0.00 & -0.10 & -0.43 & 0.01 & 0.25 & 0.69 & -0.01 & -0.58 & -1.33 & 0.00 & 0.23 & 0.25 \\
\hline Mother's age at birth & 0.30 & 9.87 & 6.42 & 0.19 & 6.29 & 3.93 & 0.07 & 4.95 & 2.20 & 0.01 & 0.58 & 0.17 \\
\hline Father’s education & 0.06 & 2.02 & 4.10 & 0.07 & 2.25 & 3.73 & -0.34 & -25.67 & -10.74 & -0.24 & -18.38 & -4.10 \\
\hline Mother's education & 0.19 & 6.26 & 5.67 & 0.17 & 5.56 & 4.71 & -0.24 & -17.75 & -12.16 & -0.20 & -15.35 & -4.40 \\
\hline Rural & 0.37 & 11.96 & 5.81 & 0.28 & 9.00 & 4.67 & 0.17 & 12.54 & 7.12 & 0.16 & 11.80 & 4.38 \\
\hline Birth year & 0.00 & 0.15 & 0.11 & 0.05 & 1.47 & 0.20 & 0.33 & 24.92 & 4.55 & 0.46 & 34.49 & 1.64 \\
\hline State & -0.17 & -5.71 & -0.45 & -0.36 & -11.72 & -0.73 & 0.07 & 5.01 & 0.37 & -0.13 & -9.97 & -0.35 \\
\hline State trends & 0.56 & 18.32 & 1.51 & 0.56 & 18.19 & 1.06 & 0.12 & 8.87 & 0.59 & -0.02 & -1.61 & -0.05 \\
\hline
\end{tabular}

See notes to Table 7 . 
Appendix Table 8A: Wealth in Under-5 Mortality Logits (odds ratios)

\begin{tabular}{lccc}
\hline & $L C$ & $H C$ & $M$ \\
\hline Wealth quartile $^{\mathrm{b}}$ & & & \\
$2^{\text {nd }}$ & 0.948 & 1.034 & 1.077 \\
& {$[-1.04]$} & {$[0.85]$} & {$[0.87]$} \\
$3^{\text {rd }}$ & $0.884^{*}$ & 0.935 & 0.888 \\
& {$[-2.07]$} & {$[-1.57]$} & {$[-1.39]$} \\
$4^{\text {th }}$ & 0.978 & $0.899^{*}$ & 0.955 \\
& {$[-0.29]$} & {$[-2.28]$} & {$[-0.50]$} \\
Observations & 39102 & 87277 & 24689 \\
\hline
\end{tabular}

Children born no more than 10 years before the survey. Full results available on request. Robust $\mathrm{z}$-statistics in brackets. ${ }^{* *} \mathrm{p}<0.01$,

$* \mathrm{p}<0.05 .{ }^{\text {b }}$ omitted category is $1^{\text {st }}$ quartile.

Appendix Table 8B: Role of Wealth in the Hindu-Muslim Under-5 Mortality Differential

\begin{tabular}{|c|c|c|c|c|c|c|c|c|c|c|c|c|}
\hline \multirow{3}{*}{ Benchmark } & \multicolumn{6}{|c|}{ Low-caste/Muslim } & \multicolumn{6}{|c|}{ High-caste/Muslim } \\
\hline & LC & & & $\mathrm{M}$ & & & $\mathrm{HC}$ & & & $\mathrm{M}$ & & \\
\hline & $\begin{array}{c}\%- \\
\text { point }\end{array}$ & $\begin{array}{c}\% \text { of } \\
\bar{Y}^{H}-\bar{Y}^{M}\end{array}$ & $\begin{array}{l}\text { z- } \\
\text { stat }\end{array}$ & $\begin{array}{c}\%- \\
\text { point }\end{array}$ & $\begin{array}{c}\% \text { of } \\
\bar{Y}^{H}-\bar{Y}^{M}\end{array}$ & z-stat & $\begin{array}{c}\%- \\
\text { point }\end{array}$ & $\begin{array}{c}\% \text { of } \\
\bar{Y}^{H}-\bar{Y}^{M}\end{array}$ & z-stat & $\begin{array}{c}\%- \\
\text { point }\end{array}$ & $\begin{array}{c}\% \text { of } \\
\bar{Y}^{H}-\bar{Y}^{M}\end{array}$ & z-stat \\
\hline Explained $^{\mathrm{a}}$ & 1.28 & 33.10 & & 0.51 & 13.16 & & -0.69 & -67.93 & & -0.95 & -93.14 & \\
\hline Unexplained $^{\mathrm{b}}$ & 2.59 & 66.90 & & 3.36 & 86.84 & & 1.72 & 167.93 & & 1.97 & 193.14 & \\
\hline
\end{tabular}

Children born no more than 10 years before the survey. Full results available on request. See also notes to

Table 7.

Appendix Table 9A: State Variables in Under-5 Mortality Logits (odds ratios)

\begin{tabular}{lccc}
\hline & $L C$ & $H C$ & $M$ \\
\hline State variables: & & & \\
Medical expenditure & 0.991 & 1.088 & 0.941 \\
& {$[-0.092]$} & {$[1.11]$} & {$[-0.45]$} \\
Development expenditure & 0.893 & 0.995 & 0.866 \\
& {$[-1.02]$} & {$[-0.058]$} & {$[-0.80]$} \\
Rural inequality & 1.093 & $1.224^{* *}$ & $1.506^{*}$ \\
& {$[0.92]$} & {$[2.63]$} & {$[2.30]$} \\
Urban inequality & 0.939 & 0.92 & 1.075 \\
& {$[-0.69]$} & {$[-1.12]$} & {$[0.35]$} \\
Net State Domestic Product & 1.22 & 1.077 & 1.075 \\
& {$[1.33]$} & {$[0.69]$} & {$[0.28]$} \\
Observations & 111700 & 260406 & 64045 \\
\hline
\end{tabular}

15 largest Indian states only. Full results available on request.

Robust z-statistics in brackets. ${ }^{* *} \mathrm{p}<0.01,{ }^{*} \mathrm{p}<0.05$. 
Appendix Table 9B: Role of State Variables in the Hindu-Muslim Under-5 Mortality Differential

\begin{tabular}{|c|c|c|c|c|c|c|c|c|c|c|c|c|}
\hline \multirow{3}{*}{ Benchmark } & \multicolumn{6}{|c|}{ Low-caste/Muslim } & \multicolumn{6}{|c|}{ High-caste/Muslim } \\
\hline & $\mathrm{LC}$ & & & $\mathrm{M}$ & & & $\mathrm{HC}$ & & & $\mathrm{M}$ & & \\
\hline & $\begin{array}{c}\%- \\
\text { point }\end{array}$ & $\begin{array}{c}\% \text { of } \\
\bar{Y}^{H}-\bar{Y}^{M}\end{array}$ & z-stat & $\begin{array}{c}\%- \\
\text { point }\end{array}$ & $\begin{array}{c}\% \text { of } \\
\bar{Y}^{H}-\bar{Y}^{M}\end{array}$ & z-stat & $\begin{array}{c}\%- \\
\text { point }\end{array}$ & $\begin{array}{c}\text { \% of } \\
\bar{Y}^{H}-\bar{Y}^{M}\end{array}$ & z-stat & $\begin{array}{c}\%- \\
\text { point }\end{array}$ & $\begin{array}{c}\% \text { of } \\
\bar{Y}^{H}-\bar{Y}^{M}\end{array}$ & z-stat \\
\hline $\bar{Y}^{H}-\bar{Y}^{M}$ & 4.75 & 100.00 & & 4.75 & 100.00 & & 1.41 & 100.00 & & 1.41 & 100.00 & \\
\hline Explained $^{\mathrm{a}}$ & 1.55 & 32.55 & & 1.24 & 26.21 & & -0.36 & -25.53 & & -0.38 & -26.68 & \\
\hline $\begin{array}{l}\text { Contribution } \\
\text { of state } \\
\text { variables }\end{array}$ & -0.03 & -0.60 & -0.24 & 0.01 & 0.21 & 0.05 & 0.07 & 5.04 & 1.13 & 0.22 & 15.41 & 1.28 \\
\hline
\end{tabular}

15 largest Indian states only. State variables: medical and development expenditure, rural and urban inequality, net state domestic product. See also notes to Table 7.

Appendix Table 10A: Village Variables in Neonatal and Infant Mortality Logits (odds ratios)

\begin{tabular}{|c|c|c|c|c|c|c|}
\hline & $\begin{array}{l}\text { Neonatal } \\
\text { mortality }\end{array}$ & & & $\begin{array}{l}\text { Infant } \\
\text { mortality }\end{array}$ & & \\
\hline & $\mathrm{LC}$ & $\mathrm{HC}$ & $\mathrm{M}$ & $\mathrm{LC}$ & $\mathrm{HC}$ & $\mathrm{M}$ \\
\hline \multirow[t]{2}{*}{ Log of village population } & 0.909 & 0.982 & 1.033 & 0.945 & 1.008 & 0.947 \\
\hline & {$[-1.65]$} & {$[-0.40]$} & {$[0.27]$} & {$[-1.13]$} & {$[0.20]$} & {$[-0.60]$} \\
\hline \multirow[t]{2}{*}{$=1$ if connected to all-weather road } & 1.035 & 0.992 & 1.264 & 0.965 & 1.037 & 1.098 \\
\hline & [0.29] & {$[-0.079]$} & [1.27] & {$[-0.34]$} & {$[0.42]$} & {$[0.58]$} \\
\hline \multirow[t]{2}{*}{$=1$ if pharmacy in village } & 1.123 & 1.255 & 1.268 & 0.885 & 1.127 & 1.238 \\
\hline & [0.69] & [1.84] & {$[1.33]$} & {$[-0.77]$} & {$[1.04]$} & [1.15] \\
\hline \multirow[t]{2}{*}{$=1$ if mahilamandal in village } & 1.123 & 1.082 & 1.126 & $1.250 *$ & 1.069 & 1.018 \\
\hline & {$[0.90]$} & {$[0.83]$} & {$[0.51]$} & {$[2.02]$} & {$[0.74]$} & [0.080] \\
\hline \multirow[t]{2}{*}{$=1$ if anganwadi in village } & 1.111 & 1.012 & 0.728 & 1.09 & 0.991 & $0.697 *$ \\
\hline & [0.93] & {$[0.14]$} & {$[-1.79]$} & [0.89] & {$[-0.10]$} & {$[-2.16]$} \\
\hline \multirow[t]{2}{*}{$=1$ if primary health centre in village } & 1.16 & 0.901 & 1.428 & 1.109 & 0.818 & 1.339 \\
\hline & {$[0.78]$} & {$[-0.74]$} & {$[1.54]$} & {$[0.58]$} & {$[-1.44]$} & [1.37] \\
\hline \multirow[t]{2}{*}{$=1$ if subcentre in village } & 0.972 & 0.873 & 0.777 & 0.944 & 0.979 & 0.918 \\
\hline & {$[-0.24]$} & {$[-1.43]$} & {$[-1.35]$} & {$[-0.56]$} & {$[-0.24]$} & {$[-0.48]$} \\
\hline \multirow[t]{2}{*}{$=1$ if hospital in village } & 0.853 & 0.964 & 0.799 & 0.949 & 1.144 & 1.286 \\
\hline & {$[-0.86]$} & {$[-0.24]$} & {$[-0.68]$} & {$[-0.31]$} & {$[0.88]$} & {$[1.01]$} \\
\hline \multirow[t]{2}{*}{$=1$ if clinic or dispensary in village } & 1.078 & 1.004 & 1.28 & 1.052 & 0.918 & 0.9 \\
\hline & {$[0.56]$} & [0.035] & [1.09] & {$[0.43]$} & {$[-0.87]$} & {$[-0.45]$} \\
\hline Observations & 11757 & 19709 & 4916 & 10022 & 16703 & 4479 \\
\hline
\end{tabular}

Children born no more than 6 years before the NFHS-2 survey only. Full results available on request. Robust z-statistics in brackets. ${ }^{* *} \mathrm{p}<0.01,{ }^{*} \mathrm{p}<0.05$. 
Appendix Table 10B: Role of Village Variables in the Hindu-Muslim Neonatal Mortality Differentials

\begin{tabular}{|c|c|c|c|c|c|c|c|c|c|c|c|c|}
\hline \multirow{3}{*}{ Benchmark } & \multicolumn{6}{|c|}{ Low-caste/Muslim } & \multicolumn{6}{|c|}{ High-caste/Muslim } \\
\hline & \multirow{2}{*}{$\begin{array}{c}\text { LC } \\
\%- \\
\text { point }\end{array}$} & \multicolumn{5}{|c|}{$\mathrm{M}$} & \multicolumn{3}{|l|}{$\mathrm{HC}$} & \multicolumn{3}{|c|}{$\mathrm{M}$} \\
\hline & & $\begin{array}{c}\% \text { of } \\
\bar{Y}^{H}-\bar{Y}^{M}\end{array}$ & z-stat & $\begin{array}{c}\%- \\
\text { point }\end{array}$ & $\begin{array}{c}\% \text { of } \\
\bar{Y}^{H}-\bar{Y}^{M}\end{array}$ & z-stat & $\begin{array}{c}\%- \\
\text { point }\end{array}$ & $\begin{array}{c}\% \text { of } \\
\bar{Y}^{H}-\bar{Y}^{M}\end{array}$ & z-stat & $\begin{array}{c}\%- \\
\text { point }\end{array}$ & $\begin{array}{c}\% \text { of } \\
\bar{Y}^{H}-\bar{Y}^{M}\end{array}$ & z-stat \\
\hline $\bar{Y}^{H}-\bar{Y}^{M}$ & 1.47 & 100.00 & & 1.47 & 100.00 & & 0.60 & 100.00 & & 0.60 & 100.00 & \\
\hline Explained $^{\mathrm{a}}$ & 0.62 & 42.38 & & -0.45 & -30.73 & & -0.77 & -127.15 & & -0.47 & -78.87 & \\
\hline Unexplained $^{\mathrm{b}}$ & 0.85 & 57.62 & & 1.92 & 130.73 & & 1.37 & 227.15 & & 1.08 & 178.87 & \\
\hline Detailed contributions: & & & & & & & & & & & & \\
\hline $\begin{array}{l}\text { Village population and } \\
\text { connection to all- } \\
\text { weather road }\end{array}$ & 0.33 & 22.58 & 1.60 & -0.11 & -7.44 & -0.31 & 0.03 & 5.14 & 0.38 & -0.04 & -6.65 & -0.18 \\
\hline Village health facilities & -0.11 & -7.23 & -0.61 & -0.34 & -23.17 & -1.64 & -0.11 & -19.05 & -1.13 & -0.23 & -38.19 & -1.28 \\
\hline
\end{tabular}

Children born no more than 6 years before the NFHS-2 survey only. See also notes to Table 7.

Appendix Table 10C: Role of Village Variables in the Hindu-Muslim Infant Mortality Differentials

\begin{tabular}{|c|c|c|c|c|c|c|c|c|c|c|c|c|}
\hline \multirow{3}{*}{ Benchmark } & \multicolumn{6}{|c|}{ Low-caste/Muslim } & \multicolumn{6}{|c|}{ High-caste/Muslim } \\
\hline & \multicolumn{3}{|l|}{$\mathrm{LC}$} & \multicolumn{3}{|l|}{$\mathrm{M}$} & \multicolumn{3}{|l|}{$\mathrm{HC}$} & \multicolumn{3}{|l|}{$\mathrm{M}$} \\
\hline & $\begin{array}{c}\%- \\
\text { point }\end{array}$ & $\begin{array}{c}\text { \% of } \\
\bar{Y}^{H}-\bar{Y}^{M}\end{array}$ & z-stat & $\begin{array}{c}\%- \\
\text { point }\end{array}$ & $\begin{array}{c}\text { \% of } \\
\bar{Y}^{H}-\bar{Y}^{M}\end{array}$ & z-stat & $\begin{array}{c}\%- \\
\text { point }\end{array}$ & $\begin{array}{c}\% \text { of } \\
\bar{Y}^{H}-\bar{Y}^{M}\end{array}$ & z-stat & $\begin{array}{c}\%- \\
\text { point }\end{array}$ & $\begin{array}{c}\% \text { of } \\
\bar{Y}^{H}-\bar{Y}^{M}\end{array}$ & z-stat \\
\hline $\bar{Y}^{H}-\bar{Y}^{M}$ & 2.31 & 100.00 & & 2.31 & 100.00 & & 0.41 & 100.00 & & 0.41 & 100.00 & \\
\hline Explained $^{\mathrm{a}}$ & 1.04 & 45.04 & & 0.13 & 5.78 & & -0.72 & -174.99 & & -0.43 & -104.22 & \\
\hline Unexplained $^{\mathrm{b}}$ & 1.27 & 54.96 & & 2.18 & 94.22 & & 1.14 & 274.99 & & 0.84 & 204.22 & \\
\hline Detailed contributions: & & & & & & & & & & & & \\
\hline $\begin{array}{l}\text { Village population and } \\
\text { connection to all- } \\
\text { weather road }\end{array}$ & 0.31 & 13.35 & 1.14 & 0.22 & 9.63 & 0.56 & -0.01 & -3.14 & -0.13 & 0.14 & 33.19 & 0.62 \\
\hline Village health facilities & 0.21 & 8.88 & 0.93 & -0.50 & -21.58 & -1.83 & -0.06 & -13.95 & -0.45 & -0.37 & -89.28 & -1.52 \\
\hline
\end{tabular}

Children born no more than 6 years before the survey only. See also notes to Table 7. 
Appendix Table 11: Malnutrition Logits (odds ratios)

\begin{tabular}{lcccccr}
\hline \multicolumn{4}{c}{ stunted } & \multicolumn{5}{c}{ wasted } \\
\hline & Low-caste & High-caste & Muslim & Low-caste & High-caste & Muslim \\
\hline \multirow{3}{*}{ 1 if child is female } & 0.997 & $1.078^{*}$ & 1.034 & $0.876^{*}$ & $0.915^{*}$ & 0.88 \\
& {$[-0.05]$} & {$[2.12]$} & {$[0.53]$} & {$[-2.17]$} & {$[-2.04]$} & {$[-1.56]$} \\
& & & & & & \\
Child birth order (omitted: first child) & & & & & \\
& & & & & & \\
Second child & $1.162^{*}$ & $1.137^{* *}$ & $1.240^{*}$ & 0.89 & $1.186^{* *}$ & 1.213 \\
& {$[1.96]$} & {$[2.65]$} & {$[2.06]$} & {$[-1.20]$} & {$[2.92]$} & {$[1.59]$} \\
Third child & 1.13 & $1.222^{* *}$ & 1.257 & 0.998 & 1.054 & 0.968 \\
& {$[1.35]$} & {$[3.50]$} & {$[1.93]$} & {$[-0.02]$} & {$[0.74]$} & {$[-0.23]$} \\
Fourth or later child & $1.321^{* *}$ & $1.492^{* *}$ & $1.385^{* *}$ & 0.969 & $1.223^{* *}$ & 1.129 \\
& {$[2.90]$} & {$[6.22]$} & {$[2.63]$} & {$[-0.29]$} & {$[2.63]$} & {$[0.85]$}
\end{tabular}

Month of birth (omitted: January)

\begin{tabular}{|c|c|c|c|c|c|c|}
\hline February & $\begin{array}{l}1.145 \\
{[0.85]}\end{array}$ & $\begin{array}{c}0.922 \\
{[-0.81]}\end{array}$ & $\begin{array}{c}0.927 \\
{[-0.47]}\end{array}$ & $\begin{array}{l}1.235 \\
{[1.29]}\end{array}$ & $\begin{array}{c}0.962 \\
{[-0.32]}\end{array}$ & $\begin{array}{c}0.893 \\
{[-0.58]}\end{array}$ \\
\hline March & $\begin{array}{l}1.017 \\
{[0.11]}\end{array}$ & $\begin{array}{l}0.826 * \\
{[-2.00]}\end{array}$ & $\begin{array}{c}0.9 \\
{[-0.65]}\end{array}$ & $\begin{array}{l}1.409 * \\
{[2.27]}\end{array}$ & $\begin{array}{c}0.805 \\
{[-1.87]}\end{array}$ & $\begin{array}{c}0.731 \\
{[-1.69]}\end{array}$ \\
\hline April & $\begin{array}{c}0.8 \\
{[-1.49]}\end{array}$ & $\begin{array}{c}0.872 \\
{[-1.45]}\end{array}$ & $\begin{array}{c}0.783 \\
{[-1.46]}\end{array}$ & $\begin{array}{c}0.976 \\
{[-0.15]}\end{array}$ & $\begin{array}{c}0.995 \\
{[-0.04]}\end{array}$ & $\begin{array}{c}0.927 \\
{[-0.38]}\end{array}$ \\
\hline May & $\begin{array}{c}0.833 \\
{[-1.22]}\end{array}$ & $\begin{array}{c}0.829 \\
{[-1.94]}\end{array}$ & $\begin{array}{c}0.732 \\
{[-1.85]}\end{array}$ & $\begin{array}{c}1.058 \\
{[0.33]}\end{array}$ & $\begin{array}{c}0.931 \\
{[-0.61]}\end{array}$ & $\begin{array}{c}0.799 \\
{[-1.13]}\end{array}$ \\
\hline June & $\begin{array}{c}0.791 \\
{[-1.66]}\end{array}$ & $\begin{array}{c}0.686 * * \\
{[-4.00]}\end{array}$ & $\begin{array}{c}0.611 * * \\
{[-2.91]}\end{array}$ & $\begin{array}{c}1.003 \\
{[0.02]}\end{array}$ & $\begin{array}{c}1.08 \\
{[0.66]}\end{array}$ & $\begin{array}{c}0.792 \\
{[-1.16]}\end{array}$ \\
\hline July & $\begin{array}{l}0.732 * \\
{[-2.26]}\end{array}$ & $\begin{array}{c}0.610 * * \\
{[-5.57]}\end{array}$ & $\begin{array}{c}0.541^{* *} \\
{[-3.84]}\end{array}$ & $\begin{array}{c}0.867 \\
{[-0.94]}\end{array}$ & $\begin{array}{c}0.91 \\
{[-0.83]}\end{array}$ & $\begin{array}{c}0.814 \\
{[-1.03]}\end{array}$ \\
\hline August & $\begin{array}{c}0.632 * * \\
{[-3.52]}\end{array}$ & $\begin{array}{c}0.635 * * \\
{[-5.26]}\end{array}$ & $\begin{array}{c}0.377^{* *} \\
{[-6.30]}\end{array}$ & $\begin{array}{c}0.81 \\
{[-1.44]}\end{array}$ & $\begin{array}{c}0.947 \\
{[-0.50]}\end{array}$ & $\begin{array}{c}0.814 \\
{[-1.13]}\end{array}$ \\
\hline September & $\begin{array}{c}0.547 * * \\
{[-4.37]}\end{array}$ & $\begin{array}{c}0.526 * * \\
{[-7.09]}\end{array}$ & $\begin{array}{c}0.524^{* *} \\
{[-3.92]}\end{array}$ & $\begin{array}{c}0.887 \\
{[-0.78]}\end{array}$ & $\begin{array}{c}0.955 \\
{[-0.41]}\end{array}$ & $\begin{array}{c}0.937 \\
{[-0.35]}\end{array}$ \\
\hline October & $\begin{array}{c}0.521 * * \\
{[-4.84]}\end{array}$ & $\begin{array}{c}0.445^{* *} \\
{[-9.38]}\end{array}$ & $\begin{array}{c}0.372 * * \\
{[-6.57]}\end{array}$ & $\begin{array}{c}0.828 \\
{[-1.25]}\end{array}$ & $\begin{array}{c}0.849 \\
{[-1.51]}\end{array}$ & $\begin{array}{l}0.638 * \\
{[-2.51]}\end{array}$ \\
\hline November & $\begin{array}{c}0.418^{* *} \\
{[-6.22]}\end{array}$ & $\begin{array}{c}0.457 * * \\
{[-8.64]}\end{array}$ & $\begin{array}{c}0.411^{* *} \\
{[-5.69]}\end{array}$ & $\begin{array}{c}0.824 \\
{[-1.28]}\end{array}$ & $\begin{array}{c}0.832 \\
{[-1.64]}\end{array}$ & $\begin{array}{c}0.610 * * \\
{[-2.64]}\end{array}$ \\
\hline December & $\begin{array}{c}0.381^{* *} \\
{[-6.78]}\end{array}$ & $\begin{array}{l}0.362^{* *} \\
{[-10.84]}\end{array}$ & $\begin{array}{c}0.351 * * \\
{[-6.74]}\end{array}$ & $\begin{array}{c}0.939 \\
{[-0.40]}\end{array}$ & $\begin{array}{c}0.875 \\
{[-1.17]}\end{array}$ & $\begin{array}{c}0.759 \\
{[-1.45]}\end{array}$ \\
\hline
\end{tabular}

Maternal age at birth (omitted: age 19-24)

\begin{tabular}{|c|c|c|c|c|c|c|}
\hline \multirow[t]{2}{*}{ Age 9-15 } & $1.675^{*}$ & $1.818 * *$ & 1.415 & 1.022 & 0.929 & 1.322 \\
\hline & [2.57] & [3.49] & [1.14] & {$[0.10]$} & {$[-0.36]$} & [0.89] \\
\hline \multirow[t]{2}{*}{ Age 16-18 } & 1.188* & $1.280 * *$ & 1.158 & 0.854 & 1.125 & 0.872 \\
\hline & [1.98] & [3.97] & [1.18] & {$[-1.45]$} & [1.57] & [-0.89] \\
\hline \multirow[t]{2}{*}{ Age 25-30 } & 0.936 & $0.816^{* *}$ & 0.95 & 1.147 & 0.962 & 1.072 \\
\hline & {$[-0.97]$} & {$[-4.40]$} & {$[-0.58]$} & [1.73] & {$[-0.67]$} & [0.64] \\
\hline \multirow[t]{2}{*}{ Age 31-49 } & 0.894 & $0.864 *$ & 0.836 & 0.987 & 1.011 & 1.027 \\
\hline & {$[-1.18]$} & {$[-2.21]$} & {$[-1.66]$} & {$[-0.11]$} & [0.13] & {$[0.20]$} \\
\hline
\end{tabular}




\begin{tabular}{|c|c|c|c|c|c|c|}
\hline \multicolumn{7}{|c|}{ Father's education (omitted: no schooling) } \\
\hline \multirow[t]{2}{*}{ Primary } & 0.903 & 0.931 & 0.901 & 0.922 & 0.979 & 1.025 \\
\hline & {$[-1.40]$} & {$[-1.27]$} & {$[-1.23]$} & {$[-1.04]$} & {$[-0.31]$} & [0.21] \\
\hline \multirow[t]{2}{*}{ Secondary } & $0.834^{* *}$ & $0.774^{* *}$ & $0.699 * *$ & $0.805^{* *}$ & 0.9 & 0.963 \\
\hline & {$[-2.74]$} & {$[-5.17]$} & {$[-3.96]$} & {$[-2.66]$} & {$[-1.78]$} & [-0.34] \\
\hline \multirow[t]{2}{*}{ Higher } & $0.684^{* *}$ & $0.603^{* *}$ & $0.690 *$ & 0.808 & $0.823 *$ & 0.866 \\
\hline & {$[-3.24]$} & {$[-6.97]$} & {$[-2.41]$} & {$[-1.47]$} & {$[-2.16]$} & {$[-0.71]$} \\
\hline \multicolumn{7}{|c|}{ Mother’s education (omitted: no schooling) } \\
\hline \multirow{2}{*}{ Incomplete primary } & 0.83 & $0.859 *$ & 0.916 & 1.119 & 0.988 & 0.998 \\
\hline & {$[-1.71]$} & {$[-2.26]$} & {$[-0.76]$} & [0.96] & {$[-0.15]$} & {$[-0.01]$} \\
\hline \multirow[t]{2}{*}{ Complete primary } & 0.798 & $0.806^{* *}$ & $0.658^{*}$ & 0.891 & 0.843 & 1.01 \\
\hline & {$[-1.64]$} & {$[-2.63]$} & {$[-2.48]$} & {$[-0.74]$} & {$[-1.57]$} & [0.05] \\
\hline \multirow{2}{*}{$\begin{array}{l}\text { Incomplete } \\
\text { secondary }\end{array}$} & $0.671^{* *}$ & $0.663^{* *}$ & $0.691 * *$ & $0.800^{*}$ & $0.829 * *$ & $0.717 *$ \\
\hline & {$[-4.48]$} & [-8.37] & [-3.52] & {$[-2.05]$} & {$[-2.85]$} & {$[-2.30]$} \\
\hline \multirow{2}{*}{$\begin{array}{l}\text { Complete secondary } \\
\text { and higher }\end{array}$} & $0.513^{* *}$ & $0.430 * *$ & 0.728 & 0.762 & $0.735^{* *}$ & 0.696 \\
\hline & {$[-4.09]$} & {$[-10.67]$} & {$[-1.70]$} & {$[-1.29]$} & {$[-3.02]$} & [-1.52] \\
\hline \multirow[t]{2}{*}{$=1$ if rural } & 1.117 & $1.135 *$ & $1.245^{* *}$ & 1.115 & 1.055 & 1.071 \\
\hline & [1.36] & {$[2.51]$} & {$[2.66]$} & [1.12] & [0.92] & [0.65] \\
\hline \multirow[t]{2}{*}{ Constant } & 2.813* & $3.182 * *$ & 2.52 & $0.078^{* *}$ & $0.057 * *$ & $0.137 *$ \\
\hline & {$[2.27]$} & {$[4.03]$} & {$[1.74]$} & {$[-3.46]$} & {$[-6.47]$} & {$[-2.41]$} \\
\hline Observations & 10476 & 25106 & 7610 & 10544 & 25159 & 7651 \\
\hline Pseudo $\mathrm{R}^{2}$ & 0.12 & 0.129 & 0.15 & 0.057 & 0.036 & 0.043 \\
\hline
\end{tabular}

Children no more than 36 months old for states where height and weight were measured in all NFHS rounds, i.e., all states except Andhra Pradesh, Madhya Pradesh, Tamil Nadu, West Bengal, and Himachal Pradesh. Year and state dummies omitted for brevity. Full results available on request. Robust $\mathrm{z}$ statistics in brackets. ** $\mathrm{p}<0.01,{ }^{*} \mathrm{p}<0.05$. 
Appendix Table 12A: Maternal Health Variables in Neonatal and Infant Mortality Logits (odds ratios)

\begin{tabular}{lccc}
\hline \multicolumn{4}{c}{$\begin{array}{c}\text { Neonatal } \\
\text { mortality }\end{array}$} \\
\hline & LC & HC & M \\
\hline \multirow{3}{*}{ Vegetarian } & & & \\
& 1.106 & $1.217^{* *}$ & 0.935 \\
$=1$ if BMI low & {$[1.05]$} & {$[2.66]$} & {$[-0.19]$} \\
& 0.991 & 0.979 & 1.089 \\
1 if BMI low*pregnant & {$[-0.12]$} & {$[-0.34]$} & {$[0.74]$} \\
& $1.792^{* *}$ & $1.934^{* *}$ & 1.194 \\
Log (Mother Height) & {$[3.18]$} & {$[3.82]$} & {$[0.62]$} \\
& $0.114^{*}$ & $0.023^{* *}$ & $0.025^{*}$ \\
Observations & {$[-2.09]$} & {$[-4.68]$} & {$[-2.57]$} \\
\hline
\end{tabular}

Children born no more than 6 years before the NFHS-2 and NFHS-3 surveys only. Full results available on request.

Robust z-statistics in brackets. ${ }^{* *} \mathrm{p}<0.01,{ }^{*} \mathrm{p}<0.05$.

Appendix Table 12B: Role of Maternal Health Variables in the Hindu-Muslim Neonatal Mortality Differentials

\begin{tabular}{|c|c|c|c|c|c|c|c|c|c|c|c|c|}
\hline \multirow{3}{*}{ benchmark } & \multicolumn{6}{|c|}{ Low-caste/Muslim } & \multicolumn{6}{|c|}{ High-caste/Muslim } \\
\hline & LC & & & $\mathrm{M}$ & & & $\mathrm{HC}$ & & & $\mathrm{M}$ & & \\
\hline & \%-point & $\begin{array}{c}\text { \% of } \\
\bar{Y}^{H}-\bar{Y}^{M}\end{array}$ & z-stat & \%-point & $\begin{array}{c}\text { \% of } \\
\bar{Y}^{H}-\bar{Y}^{M}\end{array}$ & z-stat & \%-point & $\begin{array}{l}\text { \% of } \\
{ }^{M}-\bar{Y}^{M}\end{array}$ & z-stat & \%-point & $\begin{array}{l}\text { \% of } \\
-H-\bar{Y}^{M}\end{array}$ & z-stat \\
\hline $\bar{Y}^{H}-\bar{Y}^{M}$ & 1.02 & 100.00 & & 1.02 & 100.00 & & 0.28 & 100.00 & & 0.28 & 100.00 & \\
\hline Explained $^{\mathrm{a}}$ & 0.76 & 74.22 & & 0.47 & 46.56 & & -0.14 & -48.76 & & -0.15 & -54.11 & \\
\hline $\begin{array}{l}\text { Unexplained }^{\mathrm{b}} \\
\text { Detailed contributions }^{\mathrm{c}}\end{array}$ & 0.26 & 25.78 & & 0.54 & 53.44 & & 0.41 & 148.76 & & 0.43 & 154.11 & \\
\hline Vegetarian & 0.09 & 8.72 & 1.03 & -0.05 & -4.74 & -0.19 & 0.32 & 115.49 & 2.61 & -0.09 & -31.08 & -0.20 \\
\hline BMI & -0.01 & -0.52 & -0.20 & 0.02 & 2.16 & 0.71 & -0.04 & -15.23 & -2.42 & -0.01 & -3.47 & -0.77 \\
\hline Height & 0.05 & 5.26 & 1.98 & 0.08 & 8.03 & 2.20 & -0.01 & -3.62 & -0.92 & -0.01 & -5.00 & -0.74 \\
\hline
\end{tabular}

Children born no more than 6 years before the NFHS-2 and NFHS-3 surveys only. See also notes to Table 7. 
Appendix Table 13A: Maternal Height in Under-5 Mortality Logits (odds ratios)

Under-5

\begin{tabular}{lccc}
\multicolumn{4}{c}{ Under-5 } \\
& LC & HC & M \\
\cline { 2 - 4 } Log (Mother Height) & & & \\
& $0.237^{* *}$ & $0.224^{* *}$ & $0.077^{* *}$ \\
Observations & {$[-4.57]$} & {$[-3.69]$} & {$[-4.14]$} \\
\hline
\end{tabular}

NFHS-2 and NFHS-3 surveys only. Full results available on request.

Robust z-statistics in brackets. ${ }^{* *} \mathrm{p}<0.01,{ }^{*} \mathrm{p}<0.05$.

Appendix Table 13B: Role of Maternal Height in the Hindu-Muslim Under-5 Mortality Differentials

\begin{tabular}{|c|c|c|c|c|c|c|c|c|c|c|c|c|}
\hline \multirow{3}{*}{ benchmark } & \multicolumn{6}{|c|}{ Low-caste/Muslim } & \multicolumn{6}{|c|}{ High-caste/Muslim } \\
\hline & $\mathrm{LC}$ & & & $\mathrm{M}$ & & & $\mathrm{HC}$ & & & $\mathrm{M}$ & & \\
\hline & \%-point & $\begin{array}{c}\text { \% of } \\
\bar{Y}^{H}-\bar{Y}^{M}\end{array}$ & z-stat & \%-point & $\begin{array}{c}\text { \% of } \\
\bar{Y}^{H}-\bar{Y}^{M}\end{array}$ & z-stat & \%-point & $\begin{array}{c}\text { \% of } \\
\bar{Y}^{H}-\bar{Y}^{M}\end{array}$ & z-stat & \%-point & $\begin{array}{c}\text { \% of } \\
\bar{Y}^{H}-\bar{Y}^{M}\end{array}$ & z-stat \\
\hline $\bar{Y}^{H}-\bar{Y}^{M}$ & 4.65 & 100.00 & & 4.65 & 100.00 & & 1.08 & 100.00 & & 1.08 & 100.00 & \\
\hline Explained $^{\mathrm{a}}$ & 2.09 & 45.06 & & 2.01 & 43.23 & & -0.04 & -3.95 & & -0.16 & -14.78 & \\
\hline $\begin{array}{l}\text { Unexplained }^{\mathrm{b}} \\
\text { Detailed contributions }^{\mathrm{c}}\end{array}$ & 2.55 & 54.94 & & 2.64 & 56.77 & & 1.12 & 103.95 & & 1.24 & 114.78 & \\
\hline Height & 0.12 & 2.61 & 4.50 & 0.18 & 3.84 & 3.97 & 0.03 & 2.86 & 3.03 & 0.04 & 3.56 & 2.04 \\
\hline
\end{tabular}

NFHS-2 and NFHS-3 surveys only. See also notes to Table 7. 
Appendix Figure 1

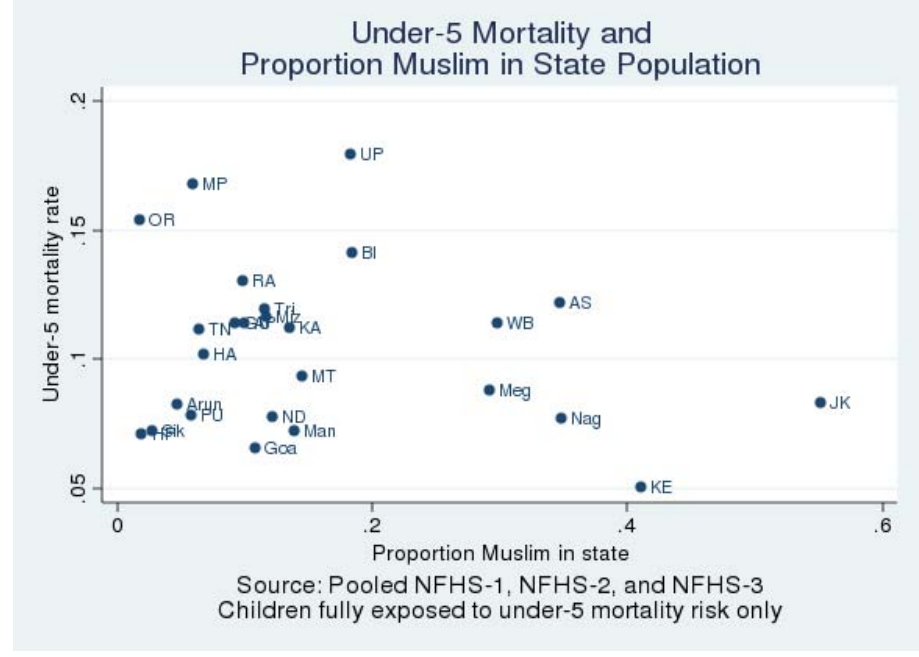

Appendix Figure 2

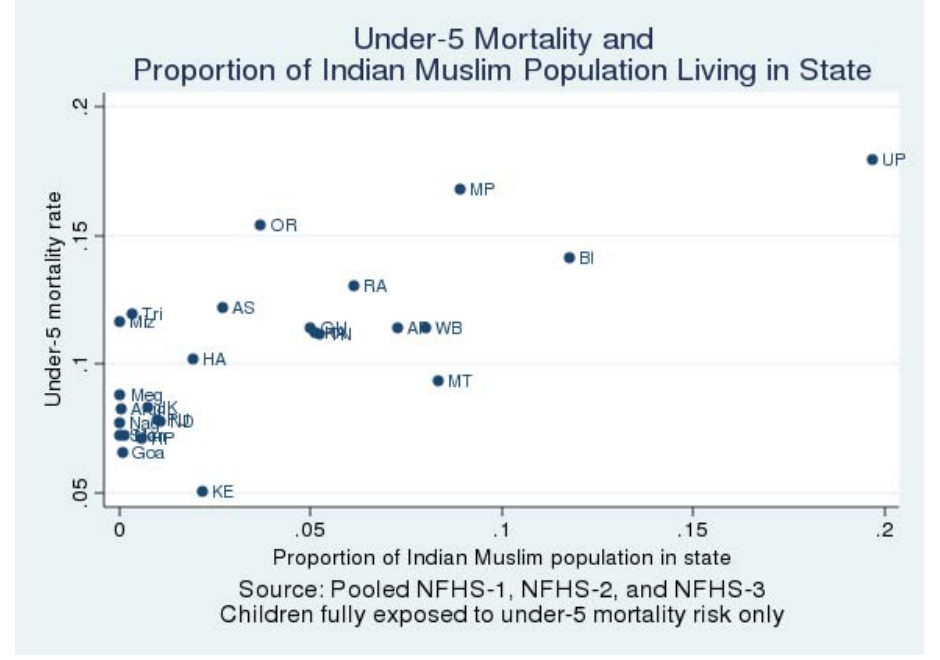

Appendix Figure 3

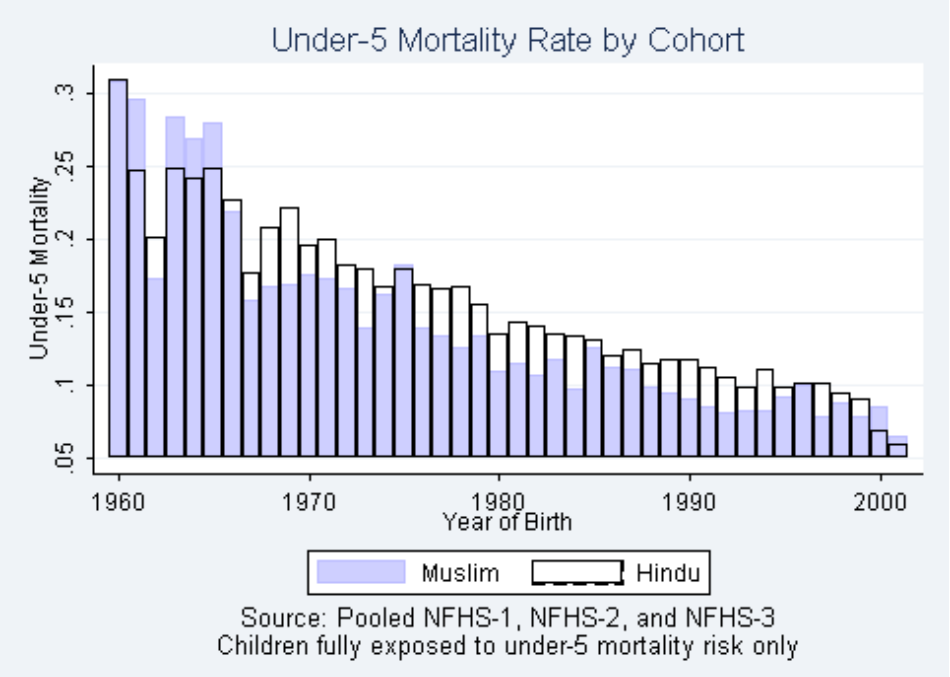

